ARCHIWA - KanCELARIE - ZBIORY

NR $5(7) / 2014$

KLAUdia JęDRZEJEWSKa

(Berlinek)

\title{
TEORETYCZNA MYŚL ARCHIWALNA KAZIMIERZA KoNARSKIEGo (1886-1972)
}

http://dx.doi.org/10.12775/AKZ.2014.002

Słow a kluczowe: myśl archiwalna; teoria archiwalna; Konarski Kazimierz; zespół archiwalny; zasada proweniencji; przedmiot archiwistyki; zakres archiwistyki; pomoce archiwalne; opracowanie zasobu archiwalnego; zarządzanie archiwami

Keywords: archival thought; archival theory; Konarski Kazimierz; archival fonds; the principle of provenance; subject of archivistics; scope of archivistics; archival aids; arrangement and description of archive; managing archives

Streszczenie

Kazimierz Konarski był przede wszystkim metodykiem. Jednak jego duże doświadczenie archiwalne pozwalało mu na wyciąganie teoretycznych wniosków i uogólnień. Praca archiwalna Konarskiego skupiała się przede wszystkim na opracowaniu zasobu archiwalnego i jego organizacji, co przyniosło wymierne korzyści metodyczne w postaci tworzenia systematyki pomocy archiwalnych oraz wytycznych metodycznych do opracowania różnych typów dokumentacji. Opracowanie zasobu archiwalnego zawsze pozostawało dla Konarskiego zagadnieniem centralnym w działalności archiwów. Jego doświadczenie w małym stopniu obejmowało problemy brakowania czy udostępniania archiwaliów. Za to sprawowanie funkcji kierowniczych w archiwach pozwoliło mu na poznanie organizacji archiwów i mechanizmów funkcjonowania 
służby archiwalnej. Działalność archiwów wyznaczała w myśli Konarskiego zakres archiwistyki. Wiodącą rolę odgrywała oczywiście problematyka porządkowania i inwentaryzacji zasobu, a wynikało to z centralnej roli zespołu archiwalnego, który był dla Konarskiego przedmiotem badań. Zakres archiwistyki widział Konarski bardzo szeroko. Włączał do niego wszystkie czynności, jakie wykonują archiwiści, w tym nawet problematykę tworzenia i prowadzenia biblioteki archiwalnej czy atmosferę w archiwum. Sam przedmiot archiwistyki zasadniczo się nie zmieniał, przeobrażeniom natomiast ulegał punkt ciężkości, nacisk, jaki Konarski kładł na poszczególne zagadnienia. Początkowo kluczową kwestią była zasada proweniencji, następnie skupił się bardziej na pojęciu samego zespołu, by ostatecznie uznać, że kamieniem węgielnym archiwistyki jest wykrystalizowanie się pojęcia aktu. Podejście takie jest ewidentnie uleganiem pewnym modom. Widać początkowe zachłyśnięcie się zasadą proweniencji, a następnie przejście, bez wątpienia pod wpływem Meissnera, na pozycje aktoznawcze. Konsekwentnie Konarski utrzymywał pogląd o konieczności stworzenia polskiej odmiany archiwistyki. Uważał, że archiwistyka nie jest nauką uniwersalną i musi posiadać swój lokalny charakter i wydaje się, że tego dokonał. Walnie przyczynił sią do stworzenia polskiej specyficznej archiwistyki, skupiającej się na zagadnieniach aktu i kancelarii, żądającej szczegółowego opisu archiwaliów, różniącej się przynajmniej w tym zakresie od archiwistyki światowej. Postać Kazimierza Konarskiego trwale wpisała się historię polskiej archiwistyki. Jednak czy może to dziwić, skoro jest on twórcą, pierwszym i być może głównym propagatorem polskiej odmiany archiwistyki?

Zaproponowane przeze mnie badanie myśli archiwalnej w jej aspekcie wyłącznie teoretycznym jest modyfikacją istniejącego już modelu badania myśli archiwalnej. W polskiej literaturze istnieją dwa modele badawcze. Pierwszy zaproponował Zdzisław Chmielewski ${ }^{1}$. Badał on myśl archiwalną na przestrzeni dwóch wieków, stwierdzając, że „myśl archiwalna oscyluje wokół archiwaliów. Wyraża się w dokonaniach koncepcyjnych, których celem jest stworzenie optymalnych warunków do gromadzenia, opracowania i zabezpieczania oraz udostępniania zasobu archiwalnego. Jej treścią pozostaje także opis rezultatów tych dokonań" ${ }^{2}$. Ponadto dodał, że praca jego skupia się głównie na zagadnieniu rozwoju metodyki archiwalnej, ale starał się także odtworzyć wiodące dokonania teoretyczne, „które miały najczęściej walor naukowego uogólnienia koncepcji metodycznych lub wyraz wysiłków poznawczych prowadzących do 1994.

${ }^{1}$ Z. Chmielewski, Polska myśl archiwalna w XIX i XX wieku, Warszawa-Szczecin 2 Tamże, s. 5. 
uchwycenia natury archiwistyki”3. Mojej pracy bliższy był oczywiście drugi omawiany przez niego aspekt badania myśl archiwalnej. Drugi model badawczy, który był dla mnie punktem wyjścia, zastosował Robert Degen, opisując myśli archiwalną Ryszarda Mienickiego ${ }^{4}$. Teoretyczne ujęcie tego modelu dał Waldemar Chorążyczewski we wstępie do analizy myśli archiwalnej Ryszarda Przelaskowskiego. Model ten zakłada opisanie jednego „myśliciela archiwalnego”, gdyż autor wyszedł z założenia, że „myśl powstaje zawsze u pojedynczego człowieka, poddanego konkretnym wpływom zewnętrznym i wywierającego wpływ na innych ludzi myślących”. Takie spojrzenie na badanie myśli implikowało konstrukcję samego modelu, który zakładał opisanie wykształcenia i doświadczenia archiwalnego archiwisty („czym nasiąknął, przygotowując się do zawodu, i czym zajmował się jako zawodowy archiwista”) i stworzenia w ten sposób biografii archiwalnej myśliciela. Dla autora „drugim blokiem zagadnień jest kształtowanie się myśli archiwalnej, pojawianie się pewnych idei, ich przekształcanie się, dojrzewanie”. Jak dodaje, „chronologia odgrywa tu ważną rolę, jako że myśl rozwija się w czasie”. Właściwa analiza miałaby odbyć się przez analizę tekstów konkretnego „archiwalnego myśliciela” ${ }^{5}$. Badanie myśli zamyka analiza recepcji dorobku. Model ten doskonale sprawdził się w przypadku badania myśli archiwisty o stosunkowo niewielkim dorobku piśmienniczym, dla mnie okazał się jednak niemożliwy do zrealizowania w pełni, gdyż twórczość Kazimierza Konarskiego obejmowała wiele prac, powstających przez dłuższy niż w przypadku Przelaskowskiego okres działalności zawodowej, i liczne wątki. Model badawczy wymagał zatem modyfikacji. W zasadniczych zrębach opiera się on na modelu opisanym przez Chorążyczewskiego. Podstawowa różnica dotyczy skupienia się wyłącznie na wątkach teoretycznych, którymi zajmował się Konarski, oraz sposobu przedstawienia problematyki. Wielowątkowość działalności Konarskiego i wymóg przejrzystości pracy skłoniły mnie do odejścia od układu ściśle chronologicznego na rzecz rzeczowego, z zachowaniem chronologii wewnątrz poszczególnych wątków. Ogrom literatury, w której powoływano się na ustalenia Konarskiego, nie pozwolił na zbadanie recepcji jego dorobku.

3 Tamże, s. 6.

${ }^{4}$ R. Degen, Myśl archiwalna Ryszarda Mienickiego, [w:] Ryszard Mienicki (1886-1956). Archiwista i historyk, red. W. Chorążyczewski i R. Degen, Toruń 2009.

5 W. Chorążyczewski, Myśl archiwalna Ryszarda Przelaskowskiego (1903-1971), [w:] W. Guzek, W. Chorążyczewski, J. Popłońska, R. Przelaskowski, Dyrektor, bibliotekarz, archiwista, Warszawa 2010, s. 79-80. 
O samym Konarskim pisano wiele ${ }^{6}$, przede wszystkim w pozycjach ogólnych omawiających archiwistykę okresu dwudziestolecia międzywojennego. Jednak zazwyczaj skupiano się na jego myśli w zakresie metodyki archiwalnej, przede wszystkim metodyki opracowania zespołu archiwalnego. Takiego Konarskiego przedstawiła Wiesława Kwiatkowska w artykule dotyczącym tradycyjnego modelu opracowania zasobu archiwalnego ${ }^{7}$ oraz kolejnym, omawiającym wpływ zasady proweniencji na metodykę opracowania zasobu archiwalnego ${ }^{8}$. Dostrzegła jednak również jego zasługi na polu teorii, jak chociażby dotyczące sformułowania zasady proweniencji i definicji zespołu archiwalnego. Jednak Bohdan Ryszewski widział w Konarskim przede wszystkim wybitnego metodyka i erudytę 9 . Zdzisław Chmielewski natomiast charakteryzował Kazimierza Konarskiego w kontekście jego podręcznika Nowożytna archiwistyka polska $i$ jej zadania ${ }^{10}$ jako dzieła najwyższej rangi, „będącego świadectwem talentu, doświadczenia, odwagi, a także i archiwalnego wyczucia autora" ${ }^{11}$. Konarskiego oceniano przede wszystkim w kontekście podręcznika, którego był autorem. Zauważono, że podręcznik był głównie wynikiem jego doświadczeń nad opracowaniem zasobu archiwalnego ${ }^{12}$. Sam podręcznik Irena Mamczak-Gadkowska i Zdzisław Chmielewski ocenili bardzo wysoko ${ }^{13}$, chociaż w opinii Andrzeja Tomczaka i Bohdana Ryszewskiego, opracowanie to, mimo że nazywane podręcznikiem, dalekie jest od wy-

6 Prócz nekrologów i biogramu w Stowniku biograficznym archiwistów polskich o Konarskim powstała obszerna i rzetelna praca magisterska: G. Jakubowski, „Kazimierz Konarski (1886-1972). Sylwetka archiwisty”, Toruń 1977.

7 W. Kwiatkowska, Tradycyjny model opracowania zasobu archiwalnego i jego znaczenie w dobie wspótczesnej, „Archiwa - Kancelarie - Zbiory” 2010, nr 1 (3).

8 Taż, Wptyw zasady proweniencji na metodykę opracowania zasobu archiwalnego $w$ Polsce, [w:] Torunskie konfrontacje archiwalne, t. 2: Teoria archiwalna wczoraj-dziśjutro, red. W. Chorążyczewski, A. Rosa, Toruń 2011.

9 B. Ryszewski, O badaniach i dorobku archiwistyki polskiej z lat 1918-1939, „Acta Universitatis Nicolai Copernici, Historia” 1984, nr 19, s. 176, 188.

10 K. Konarski, Nowożytna archiwistyka polska i jej zadania, Warszawa 1929.

11 Z. Chmielewski, Polska myśl archiwalna, s. 71.

12 Tamże, s. 71, H. Robótka, B. Ryszewski, A. Tomczak, Archiwistyka, Warszawa 1989, s. 345; B. Ryszewski, O niektórych podstawowych pojęciach archiwalnych (kancelaria, registratura, zespót archiwalny, archiwum), „Zeszyty Naukowe UMK, Historia” 1969, nr 5, s. 94; I. Mamczak-Gadkowska, Archiwa państwowe w II Rzeczypospolitej, Poznań 2006, s. 349

13 I. Mamczak-Gadkowska, dz. cyt., s. 350; Z. Chmielewski, Polska myśl archiwalna, s. 71 . 
czerpania całości problematyki archiwalnej ${ }^{14}$. Często opisywano podręcznik Kazimierza Konarskiego łącznie z opracowaniem Ryszarda Przelaskowskiego, będącym według wielu rozwinięciem myśli Konarskiego ${ }^{15}$. W duchu porównania tych prac powstał także artykuł mojego autorstwa, ukazujący podejście Konarskiego do archiwistyki ${ }^{16}$.

Prace te pozwoliły na ogólne nakreślenie tła czasów, w jakich Konarskiemu przyszło pracować, by móc wyjaśnić jego poglądy. Jednak podstawą do nakreślenia archiwalnej biografii Kazimierza Konarskiego były dla mnie sprawozdania z działalności archiwów państwowych zamieszczone w przedwojennych numerach „Archeionu”. Dla opisania powojennej działalności przedstawianego badacza konieczne okazało się przeprowadzenie kwerendy w Archiwum Zakładowym Archiwum Głównego Akt Dawnych i przeanalizowanie tamtejszych sprawozdań oraz protokołów posiedzeń różnych ciał kolegialnych. Cennym uzupełnieniem tych źródeł były wspomnienia Kazimierza Konarskiego ${ }^{17}$ oraz zachowany w zasobie Archiwum Polskiej Akademii Nauk w Warszawie jego dziennik czynności archiwalnych ${ }^{18}$.

Niemniej jednak podstawą do moich zasadniczych rozważań są dzieła Konarskiego, zarówno te publikowane, jak i niepublikowane. Wykorzystane prace niepublikowane przechowywane są w Archiwum Zakładowym AGAD i w Archiwum PAN w Warszawie. Niczego natomiast nie wniosła kwerenda w spuściźnie Kazimierza Konarskiego przechowywanej w Bibliotece Narodowej w Warszawie.

${ }_{14}$ B. Ryszewski, O badaniach i dorobku, s. 187; A. Tomczak, Archiwistyka polska (1918-1969). Z dziejów ksztattowania się dyscypliny naukowej i jej nazwy, „Rocznik Biblioteki Narodowej" 1972, r. 7, s. 157.

15 Por. I. Mamczak-Gadkowska, dz. cyt., s. 350.

${ }^{16}$ K. Leśniewska, „Program prac wewnętrznych w archiwach nowożytnych” Ryszarda Przelaskowskiego jako rozwinięcie myśli Kazimierza Konarskiego czy inne spojrzenie na archiwistykę?, „Archiwista Polski” 2012, nr 1 (65).

${ }^{17}$ K. Konarski, Dalekie a bliskie. Wspomnienia szczęśliwego cztowieka, Wrocław-Warszawa-Kraków 1965.

${ }_{18}$ Archiwum Polskiej Akademii Nauk w Warszawie [dalej: APAN], Materiały Kazimierza Konarskiego, sygn. 5, „Raptularz”, „Dziennik prac”. Notatki z wykonywanych prac archiwalnych, 1945-1950, 1953-1954. 


\section{Biografia ARCHIWALNA KaZIMIERZa KonarSKIEgo}

Kazimierz Konarski wraz z Stefanem Ehrenkreutzem i Antonim Rybarskim, 11 listopada 1918 roku, z rąk Adolfa Warschauera przejął w imieniu władz polskich archiwa pozostające dotychczas pod zarządem niemieckim. Konarski czynił to jednak nie jako archiwista czy urzędnik administracji archiwalnej, ale jako przedstawiciel Ministerstwa Wyznań Religijnych i Oświecenia Publicznego, w którym od 2 października 1917 r. (początkowo w Departamencie Wyznań Religijnych i Oświecenia Publicznego przy Tymczasowej Radzie Stanu) pełnił funkcję sekretarza generalnego ${ }^{19}$. Jednak, jak stwierdził Michał Wąsowicz w swoim przemówieniu wygłoszonym na uroczystości 40-lecia pracy Konarskiego, „widocznie bakcyl archiwalny, z jakim wówczas zetknął się prof. Konarski, trafił na sprzyjające warunki, skoro w niespełna trzy lata później, dzisiejszy nasz Jubilat, a wówczas 35-letni wysoki urzędnik Ministerstwa Oświaty zrezygnował z otwierającej się przed nim kariery w Ministerstwie i zdecydował się na żmudną, nieefektowną i prawie bezimienną pracę archiwalną" 20 .

Nieco inaczej wspominał początek swojego długoletniego związku z archiwami sam Konarski. Praca w MWRiOP stopniowo stawała się dla niego nużąca. Jak mówił, „rola oliwiarki, wiekuistego pośrednika, bez własnego wyraźnego zakresu pracy i wyraźnych, konkretnych jej rezultatów przejadła mi się już zupełnie”. Wpłynęło to na jego chęć rozstania się z Ministerstwem, a szansa na to przyszła do niego sama. Jak pisał w swych wspomnieniach: „Kiedyś, późnym latem 1921 r., zgłosił się do mnie telefonicznie ówczesny dyrektor Archiwów Państwowych, Józef Paczkowski, z propozycją odbycia spaceru, przy czym dawał do zrozumienia, że chce ze mną poufnie pogadać. [...] Było to nad Wisłą. Po raz drugi w ciągu paru ostatnich lat los mego życia miał się rozstrzygnąć nad Wisłą, gdyż tamże, w pobliżu mostu Poniatowskiego, odbyły się moje oświadczyny. Tym razem miało miejsce coś pokrewnego, tyle że ja byłem teraz stroną bierną, nie czynną. Oto po pewnym wstępie

19 W. Maciejewska, Konarski Kazimierz Bogdan (1886-1972), [w:] Stownik biograficzny archiwistów polskich, red. M. Bielińska, I. Janosz-Biskupowa, t. 1: 1918-1984, Warszawa-Łódź 1988, s. 104.

20 Przemówienie doc. dra Michata Wasowicza wygtoszone na uroczystości 40-lecia pracy archiwalnej prof. dra Kazimierza Konarskiego dnia 21 X 1961, „Archeion” 1962, t. 37, s. 301. 
zadeklarował mi p. dyrektor gotowość przyjęcia mnie w szranki archiwistów w wypadku, gdybym zdecydował się opuścić Ministerstwo. Wakowało stanowisko dyrektora Archiwum Akt Dawnych w Warszawie, które zostało mi zaproponowane" 21 .

Mimo wielu obaw, Konarski przyjął zaproponowaną mu posadę. Największym lękiem napawał go brak doświadczenia w pracy archiwalnej. Konarski był absolwentem Warszawskiej Szkoły Realnej, jednak strajk szkolny w 1905 r. uniemożliwił mu zdanie tam matury, którą ostatecznie uzyskał w 1906 r. w Krakowie w I Szkole Realnej. Chęć kontynuowania nauki na uniwersytecie zmusiła go do rozszerzenia matury o maturę gimnazjalną typu humanistycznego, którą zdał w Krakowie w 1907 r. Tego samego roku rozpoczął studia z zakresu historii na Uniwersytecie Jagiellońskim. Jako specjalizację wybrał historię nowożytną, pod kierunkiem prof. Wiktora Czermaka, uzyskując w 1913 r. tytuł doktora na podstawie rozprawy Polska przed odsieczq wiedeńska w roku 168322. Praca ta oparta była na dużej podstawie źródłowej. Konarski w czasie jej pisania korzystał z zasobu archiwów warszawskich, zbiorów Ossolineum, a także z archiwów wiedeńskich ${ }^{23}$. Już po uzyskaniu stopnia doktora w tym samym roku otrzymał stypendium zagraniczne, którego celem było poszerzenie studiów nad tematem rozprawy doktorskiej o materiały znajdujące się w Głównym Archiwum Krajowym w Dreźnie i archiwach paryskich ${ }^{24}$.

Był to jednak jego jedyny kontakt $\mathrm{z}$ archiwami, gdyż dalej kariera zawodowa Konarskiego przebiegała w instytucjach oświatowych - najpierw jako nauczyciela w prywatnych szkołach (1914), później, przez rok wykładowcy na Uniwersytecie Warszawskim (1915/1916), następnie na wspomnianym już stanowisku sekretarza generalnego w MWRiOP od 1917 r. ${ }^{25}$

Zadanie miał w pewnym sensie utrudnione. W swoich wspomnieniach zarysował obraz cichego konfliktu, jaki miał miejsce między nim a Januszem Iwaszkiewiczem, który pełnił funkcję kierownika archiwum, zanim na jego czele stanął Konarski. Jak wspominał: „Napięte stosunki z Iwaszkiewiczem nie pozwoliły mej ambicji posłużyć się nim jako ciceronem po zakamarkach archiwalnych, stąd też wszelkie nocje, zarówno dotyczące zawartości archi-

\footnotetext{
21 K. Konarski, Dalekie a bliskie, s. 219-220.

22 W. Maciejewska, dz. cyt., s. 104.

23 K. Konarski, Dalekie a bliskie, s. 157.

24 W. Maciejewska, dz. cyt., s. 104.

25 Tamże.
} 
wum, jak i metodyki pracy, musiałem zdobyć własną pracą. Inna rzecz, że w początkach robiłem błędy jeden za drugim i ze zgrozą przypominam sobie różne moje rewolucyjne metody porządkowania akt" ${ }^{26}$. Jednak prace, jakie przeprowadził w archiwum, doprowadziły go z czasem do wypracowania metod, z których korzystali inni archiwiści. A rozmiar i zakres tych prac był bardzo szeroki.

Konarski zajmował się przede wszystkim inwentaryzacją zasobu Archiwum Akt Dawnych. Przeprowadzał ją samodzielnie bądź we współpracy z innymi archiwistami AAD. W taki sposób opracowane zostały akta władz centralnych powstania 1830/1831, akta Rządu Narodowego, Dyktatury, Rady Najwyższej Narodowej, które uporządkował wspólnie z Ryszardem Przelaskowskim i Januszem Iwaszkiewiczem. Również we współpracy z nimi powstał inwentarz Akt Rady Stanu Królestwa Polskiego z lat 1861-1867. Z Przelaskowskim porządkował także akta wojskowe z lat 1829-1848 oraz akta Komitetu Urządzającego (wraz z słuchaczami kursu archiwalnego). We współpracy z Karolem Chodynickim powstał inwentarz kartkowy akt Komisji Rządowej Wojny z lat 1815-1831. Zajmował się także uzupełnianiem lub kontynuacją istniejących już inwentarzy. Ze Stanisławem Sołtanem i Aleksandrem Powierzą kontynuował przerwaną inwentaryzację akt Kancelarii Generał Gubernatora Warszawskiego z lat 1907-1917, samodzielnie uzupełniał inwentarz akt Generał Gubernatora Wojennego z lat 1831-1862 ${ }^{27}$. W 1928 r. kontynuował prace nad porządkowaniem i inwentaryzacją akt Generał Gubernatora Warszawskiego i Komisji Rządowej Wojny ${ }^{28}$. W związku z ostatecznym uporząd kowaniem pewnych partii zespołów postanowiono przystąpić do opracowywania referatów dotyczących kancelarii, registratury i archiwum danego urzędu. Konarskiemu w udziale przypadło opracowanie referatu na temat Kancelarii Komisji Rządowej Wojny ${ }^{29}$.

Późniejsze prace inwentaryzacyjne Konarskiego obejmowały oprócz akt urzędowych także akta ze zbiorów prywatnych. Uporządkował i rozsegregował miscellanea nabyte ze zbiorów hr. Łosia, wydzielając z nich kilka jedno-

26 Tamże, s. 222.

27 Archiwum Akt Dawnych w Warszawie w latach 1918-1926, „Archeion” 1927, t. 2 , s. $158-160$.

28 Sprawozdanie z dziatalności Archiwów Państwowych, rok 1928, 1929, red. W. Łopaciński, „Archeion” 1930, t. 6-7, Dział Urzędowy, s. 14, 73.

29 Sprawozdanie z dziatalności Archiwów Państwowych, rok 1927, red. W. Łopaciński, „Archeion” 1930, t. 5, Dział Urzędowy, s. 32. 
litych pod względem treści woluminów, dotyczących głównie Towarzystwa Przyjaciół Nauk (1931) ${ }^{30}$. Przystąpił także do prac porządkowych nad aktami Konsystorza Prawosławnego (z Z. Skowrońską) ${ }^{31}$. Nadal jednak w głównej mierze koncentrował się wokół akt urzędowych, porządkując przez kilka kolejnych lat akta Oberpolicmajstra Warszawskiego, Kancelarii Generał Gubernatora Warszawskiego oraz Dyrekcji Ubezpieczeń ${ }^{32}$.

Równocześnie z pracami inwentaryzacyjnymi Konarski pracował nad pogłębieniem informacji o zawartości opracowywanych zespołów, tworząc do nich skorowidze. Tak powstały: skorowidz kartkowy do akt stanów służby i dymisji oficerskich z akt Komisji Rządowej Wojny (opracowane z słuchaczami kursu archiwalnego i A. Januszem ${ }^{33}$ oraz indeksy rzeczowe, imienne i geograficzne do akt kancelarii Generał Gubernatora ${ }^{34}$.

Dodatkowo wraz ze współpracownikami po opracowaniu pewnej części zasobu wykonywał prace inwentaryzacyjne wykraczające poza zakres pojedynczego zespołu archiwalnego. Z Powierzą stworzył inwentarz inwentarzy AAD, który zawierał informacje o datach zespołów, ich urzędowym tytule, stanie liczebnym, sygnaturze topograficznej i zaopatrzony był w ewentualne uwagi. W zamierzeniu było także przygotowanie łącznej monografii zasobu archiwalnego, na którą składać się miały drugie egzemplarze referatów na temat kancelarii, registratury i archiwum urzędu ${ }^{35}$. W 1930 r. wraz z Przelaskowskim i Powierzą Konarski przystąpił do rewizji i ustalenia zasad reorganizacji zbioru inwentarzy archiwalnych i w związku z tym opracowany został schemat księgi dezyderatów ${ }^{36}$.

W kolejnych latach w związku z zamierzonym wydawnictwem „Vademecum Archiwalne” prace archiwistów z AAD, w tym dyrektora Konarskiego, skupiły się wokół tworzenia i organizacji centralnych pomocy archiwal-

30 Sprawozdanie z dziatalności Archiwów Państwowych, rok 1931, oprac. W Łopaciński, „Archeion” 1932, t. 10, Dział Urzędowy, s. 6.

31 Sprawozdanie z dziatalności Archiwów Państwowych, rok 1935, oprac. A. Rybarski, „Archeion” 1936, t. 14, s. 107.

32 Sprawozdanie z dziatalności Archiwów Państwowych, rok 1937, oprac. A. Rybarski, „Archeion” 1938-1939, t. 16, s. 161.

33 Archiwum Akt Dawnych w Warszawie, s. 158.

34 Sprawozdanie z dziatalności Archiwów Państwowych, rok 1928, 1929, s. 14.

35 Archiwum Akt Dawnych w Warszawie, s. 160-161.

36 Sprawozdanie z dziatalności Archiwów Państwowych, rok 1930, red. W Łopaciński, „Archeion” 1931, t. 9, Dział Urzędowy, s. 36. Konarski nie sprecyzował ani wówczas, ani w Podstawowych zasadach archiwistyki, czym dokładnie miała być ta księga. 
nych. Gromadzono materiały do schematu urzędów, prowadzono kartotekę zespołów, reorganizowano inwentarz generalny oraz topograficzny zespołów znajdujących się w AAD ${ }^{37}$. W 1934 r. stworzono szczegółowy projekt „Vademecum Archiwalnego" do akt XIX w. oraz sporządzono schemat władz i urzędów Księstwa Warszawskiego i Królestwa Polskiego ${ }^{38}$. Wśród prac, w które zaangażowani byli wszyscy pracownicy archiwum, w tym Konarski, było opracowywanie odpowiedzi na ankietę archiwalną. Natomiast z Ryszardem Przelaskowskim uporządkował, zarejestrował i zindeksował Centralną Kartotekę Zespołów, zdeponowaną przez Wydział Archiwów Państwowych w AAD ${ }^{39}$. Warto także podkreślić, że w latach 1931-1935 brał on udział w opracowywaniu normatywów wewnętrznych dla Archiwum i przeprowadzał skontrum zasobu ${ }^{40}$.

Cennym i nowatorskim jak na te czasy przedsięwzięciem, jakie wyniknęło ze współpracy Konarskiego z Przelaskowskim, było inwentaryzowanie materiałów kartograficznych wchodzących w skład zasobu AAD. Inwentarz kartografików podzielili oni na dwie części - księgi inwentarzowe, z których pierwsza służyła do inwentaryzacji map wchodzących w skład właściwego zbioru kartograficznego, druga zaś do inwentaryzowania map i planów wszytych do akt w postaci załączników. Dla obu łącznie opracowane zostały wyczerpujące skorowidze wszystkich trzech typów ${ }^{41}$. Konarski po uporządkowaniu głównego zbioru kontynuował prace inwentaryzacyjne nad kartografikami wchodzącymi w skład zespołów, inwentaryzując mapy wszyte do opracowywanych przez niego akt Kancelarii Generał Gubernatora, a także zinwentaryzował ze Skowrońską zbiór map rewindykowanych z Rosji ${ }^{42}$. Ze sprawozdania za 1931 r. dowiadujmy się, że prace inwentaryzacyjne Konarskiego i Przelaskowskiego nad zbiorami kartograficznymi były kontynuowane. Ukończyli oni „inwentarz księgowy” i segregację rzeczową inwentarza kartkowego oraz zinwentaryzowali mapy będące częścią składową wolumi-

37 Sprawozdanie z dziatalności Archiwów Państwowych, rok 1932, oprac. W Łopaciński, „Archeion” 1933, t. 11, s. 105.

38 Sprawozdanie z dziatalności Archiwów Państwowych, lata 1933 i 1934, oprac. A. Rybarski, „Archeion” 1935, t. 3, s. 194.

39 Sprawozdanie z dziatalności Archiwów Państwowych, rok 1935, s. 107.

40 Por.: Sprawozdanie z dziatalności Archiwów Państwowych, rok 1932, s. 104; Sprawozdanie z dziatalności Archiwów Państwowych, lata 1933 i 1934, s. 194-195; Sprawozdanie z dziatalności Archiwów Państwowych, rok 1935, s. 107.

${ }^{41}$ Archiwum Akt Dawnych w Warszawie, s. 160.

42 Sprawozdanie z dziatalności Archiwów Państwowych, rok 1928, 1929, s. 14, 73. 
nów ${ }^{43}$. Mimo informacji o zakończeniu inwentaryzacji zbioru kartograficznego, który w końcu 1932 r. liczył 1272 mapy i plany, w tym 366 wszytych do $\mathrm{akt}^{44}$, Konarski w następnych latach kontynuował inwentaryzację nabytków zbioru kartograficznego ${ }^{45}$.

Kolejnym polem, na którym swoją aktywność archiwalną wykazywał Konarski, była problematyka brakowania akt. W 1929 r. z ramienia WAP wraz z drem Leonem Białkowskim został skierowany do skontrolowania i wydania orzeczenia w sprawach związanych z brakowaniem akt w Archiwum Państwowym w Kielcach ${ }^{46}$. Wydział zlecił mu także „ustalenie, w porozumieniu z Komendą Główną Policji Państwowej, zasad brakowania w niższych organach administracji policyjnej. Po odbyciu kilku konferencji w tej sprawie oraz wizji lokalnej w jednym z komisariatów policji, odnośne [do] zasady ustalono i protokół ich przesłano do zatwierdzenia WAP"47. Konarski znał problematykę brakowania z praktyki, gdyż ze współpracownikami przeprowadzał je w zespołach przechowywanych w AAD. Były to akta Oberpolicmajstra Warszawskiego (z Powierzą i Iwaszkiewiczem, później Próchnikiem i Milewskim) oraz akta Zarządu Powiatowego Warszawskiego (z Próchnikiem i Milewskim ${ }^{48}$. Z Próchnikiem, Milewskim i Bachulskim wykonał także szereg prac nad brakowaniem akt Rządu Gubernialnego Warszawskiego wforcie im. Sokolnickiego ${ }^{49}$. Zabierał także głos w sprawach związanych z brakowaniem akt, wygłaszając na konferencji dyrektorów archiwów zwołanej w związku $\mathrm{z}$ trudnościami w stosowaniu przepisów dotyczących brakowania akt, referat pt. Instruowanie personelu sktadnic: potrzeby $i$ zamierzenia ${ }^{50}$.

Działalność Kazimierza Konarskiego nie zamykała się jednak w murach archiwum przy Jezuickiej. W sprawozdaniu z działalności WAP zamieszczonym w tomie czwartym Archeionu otrzymujemy informację, że „Dyr. Konarski zorganizował z własnej inicjatywy specjalne kursy archiwalne, oparte

43 Sprawozdanie z dziatalności Archiwów Państwowych, rok 1931, s. 5.

44 Sprawozdanie z dziatalności Archiwów Państwowych, rok 1932, s. 103.

45 Sprawozdanie z dziatalności Archiwów Państwowych, lata 1933 i 1934, s. 195.

46 Sprawozdanie z dziatalności Archiwów Państwowych, rok 1928, 1929, s. 2.

47 Tamże, s. 136.

48 Tamże, s. 14; Sprawozdanie z dziatalności Archiwów Państwowych, lata 1933 i 1934, s. 195; Sprawozdanie z dziatalności Archiwów Państwowych, rok 1936, oprac.

A. Rybarski, „Archeion” 1937-1938, t. 15, s. 160.

49 Sprawozdanie z dziatalności Archiwów Państwowych, rok 1935, s. 108.

50 Sprawozdanie z dziatalności Archiwów Państwowych, rok 1937, s. 142. 
później o Wydział i pod egidą Wydziału prowadzone"51. Kazimierz Konarski stawiany jest tu jako główny, jeśli nie jedyny inicjator kursów archiwalnych. Znów jednak jego wspomnienia rzucają nieco inne światło na tę kwestię. Konarski w swym pamiętniku podkreśla, że współpraca z Ryszardem Przelaskowskim owocowała nie tylko licznymi pracami nad porządkowaniem zasobu AAD, ale niezliczone dyskusje, których „wysłuchały cierpliwie akta w magazynach archiwalnych" 52 , doprowadziły do tworzenia przez nich wspólnie wielu teorii, tak że czasami trudno było ocenić, który pomysł należy do kogo. Tak też było w przypadku kursów archiwalnych ${ }^{53}$.

Można zaryzykować stwierdzenie, że Konarski prowadził także w niewielkim zakresie działalność popularyzatorską. Pełnił funkcję zastępcy komisarza służby archiwalnej na Powszechnej Wystawie Krajowej w Poznaniu. Na posiedzeniu Rady Archiwalnej w 1928 r. omówił sprawę udziału archiwów państwowych w tej wystawie. Efektem tej działalności była zorganizowana przez niego rok później wystawa dotycząca archiwów państwowych w pawilonie MWRiOP ${ }^{54}$.

Ponadto Konarski pełnił funkcje w różnego rodzaju komisjach lub organizacjach. W 1923 r. przebywał w Moskwie, biorąc udział w pracach Polskiej Delegacji w Komisji Mieszanej, Reewakuacyjnej i Specjalnej, której celem była rewindykacja na podstawie traktatu ryskiego archiwaliów wywiezionych w różnych okresach do Rosji55. Był też członkiem komisji mającej zająć się scaleniem archiwaliów, a także rzeczoznawcą w komisji archiwalnej magistratu miasta Łodzi, w której jego zadaniem było udzielanie fachowych rad i wskazówek. Brał także udział w pracach Komisji Kwalifikacyjnej przy MWRiOP powołanej do wydawania opinii o kwalifikacjach osób starających się na stanowiska w archiwach oraz był członkiem Komisji Egzaminacyjnej dla kandydatów na stanowiska I, II i III kategorii w służbie administracji archiwalnej ${ }^{56}$.

51 Protokót posiedzeń V sesji Rady Archiwalnej, „Archeion” 1928, t. 4, s. 191.

52 K. Konarski, Dalekie a bliskie, s. 233.

53 Tamże, s. 234.

54 Sprawozdanie z dziatalności Archiwów Państwowych, rok 1927, s. 5; Sprawozdanie z dziatalności Archiwów Państwowych, rok 1928, 1929, s. 136.

55 K. Konarski, Dalekie a bliskie, s. 261.

56 Sprawozdanie z dziatalności Archiwów Państwowych, rok 1928, 1929, s. 15; Sprawozdanie z dziatalności Archiwów Państwowych, rok 1928, 1929, s. 2; Dziat Urzędowy. Ruch stuzbowy, „Archeion” 1930, t. 8, s. 42. 
Konarski był także aktywnym członkiem Sekcji Archiwalnej Towarzystwa Miłośników Historii w Warszawie. W latach 1931-1935 był zastępcą przewodniczącego sekcji, dodatkowo pełnił funkcję przewodniczącego Komisji Wydawniczej, która zajmowała się wydawaniem broszur w ramach Wydawnictw Kursów Archiwalnych ${ }^{57}$.

Po wybuchu II wojny światowej i przejęciu władzy nad archiwami przez Archivamt (niemiecki zarząd archiwów) Konarski pozostał na piastowanym przez siebie stanowisku dyrektora Archiwum Akt Dawnych, ale jak pisał w swoich wspomnieniach, nastąpiło zamrożenie prac archiwalnych. Nie wykonywano kwerend, archiwum nie odwiedzali użytkownicy, nie wykonywano także prac inwentaryzacyjnych. Jedynym obowiązkiem pracowników AAD było wykonywanie prac zleconych przez okupanta, czyli wydzielanie akt dotyczących terytoriów, które miały być włączone do Rzeszy. Zadanie to realizowano jednak niechętnie, sabotując jednocześnie jego wykonanie przez maksymalne spowolnienie tempa pracy ${ }^{58}$. Jedyną pracą, którą Konarski wykonywał z przyjemnością, było przetłumaczenie z rosyjskiego na niemiecki inwentarza zespołu akt Ministra Sekretarza Stanu Księstwa Warszawskiego. Zespół ten powstawał w Dreźnie w czasach Księstwa Warszawskiego, dlatego zainteresował się nim dyrektor tamtejszego archiwum, dr Hellmut Kretzschmar. Działalność tę Konarski wspomina jako „miłe i ciekawe miesiące trudnej, ale bardzo kulturalnej i ciekawej pracy"59.

Konarski brał udział w pracy konspiracyjnej, w zakresie przygotowywania regulaminów na czas przejęcia archiwów z rąk niemieckich przez Polaków ${ }^{60}$.

Po powstaniu warszawskim, w którym zniszczeniu uległo $80 \%$ dawnego zasobu AAD, Konarski uczestniczył w ratowaniu ocalałych archiwaliów, zbiorów bibliotecznych i muzealnych. Ocalały zasób AAD został włączony do zasobu AGAD, a Konarski związał swą działalność właśnie z tym archiwum. Warto zaznaczyć, iż w aktach osobowych Konarskiego widnieje informacja, iż 16 kwietnia 1945 r. został mianowany przez Ministra Oświaty kierownikiem Archiwum Akt Dawnych, co jednak w praktyce oznaczało

57 Sprawozdanie z dziatalności Archiwów Państwowych, rok 1935, s. 171; Sprawozdanie z dziatalności Archiwów Państwowych, rok 1937, s. 210.

58 K. Konarski, Dalekie, a bliskie, s. 357.

59 Tamże, s. 358.

60 Tamże, s. 359. 
funkcję zastępcy dyrektora $\mathrm{AGAD}^{61}$. W związku z tym dużo czasu zajmowała Konarskiemu praca organizacyjna w archiwum. Sprawował ogólne kierownictwo w pracach na Forcie im. Sokolnickiego ${ }^{62}$. Ponadto jako wicedyrektor archiwum do 1957 r. często zastępował dyrektora w jego obowiązkach służbowych $^{63}$. Dla przykładu można podać, że w jego planie pracy na $1949 \mathrm{r}$. przewidzianych było wiele zadań stricte archiwalnych, a tymczasem ze sprawozdania wynika, że niemal nic z tego nie wykonał, można stąd wnosić, że nieoczekiwanie spadły na niego realne obowiązki dyrektorskie ${ }^{64}$. W 1957 r. zrzekł się stanowiska wicedyrektora, pozostając na stanowisku samodzielnego pracownika nauki i kierownika oddziału III AGAD (akt XIX wieku) ${ }^{65}$.

Po zakończeniu II wojny światowej Konarski powrócił przede wszystkim do swej głównej działalności archiwalnej, czyli porządkowania i inwentaryzacji archiwaliów. Kierował pracami porządkowymi w Forcie im. Sokolnickiego na Żoliborzu i tam w początkowym okresie wykonywał swe główne prace inwentaryzacyjne ${ }^{66}$. W czerwcu 1945 r. uporządkował i zaopatrzył w inwentarz sumaryczny zespół Tajnej Kancelarii Wielkiego Księcia Konstantego, na-

61 Archiwum Główne Akt Dawnych w Warszawie [dalej: AGAD], Archiwum Zakładowe AGAD [dalej: AZ], sygn. 39/229, Akta osobowe Kazimierza Konarskiego, s. 1. Brak w aktach osobowych informacji zawartej w SBAP, jakoby Konarski miał 16 kwietnia 1945 r. zostać mianowanym na wicedyrektora AGAD. Bez wątpienia pełnił on funkcję zastępcy dyrektora AGAD, jednak trudno jednoznacznie określić, jakie stanowisko formalnie zajmował, gdyż w ankiecie personalnej z 6 lutego 1950 r. jako charakter służbowy wpisał prowizoryczny kierownik AAD w Warszawie (s. 16), natomiast w ankiecie personalnej wypełnionej 21 kwietnia $1950 \mathrm{r}$. w punkcie praca zawodowa wpisał okres IX 1921-VIII 1944 r. Archiwum Akt Dawnych - dyrektor, I 1945-IV 1950 Archiwum Główne Akt Dawnych - wicedyrektor (s. 22-23).

62 AGAD, AZ, sygn. 66, Sprawozdania z działalności AGAD za 1946 r., s. 21; sygn. 67,Sprawozdania z działalności AGAD za 1947 r., s. 10.

63 Tamże, sygn. 70, Sprawozdania z działalności AGAD za 1950 r., s. 64.

64 Tamże, sygn. 17, Plan pracy AGAD na 1. 1947-1949, s. 7-9; sygn. 69, Sprawozdanie z działalności AGAD za 1949 rok. Wykonywanie licznych obowiązków dyrektorskich przez Konarskiego spowodowane było w głównej mierze częstymi wyjazdami ówczesnego dyrektora AGAD, Adama Stebelskiego, który zajmował się rewindykacją archiwaliów z Niemiec. Por. W. Stępniak, Misja Adama Stebelskiego. Rewindykacja archiwaliów polskich z Niemiec w latach 1945-1949, Warszawa-Łódź 1989, s. 30 i nast.

65 AGAD, AZ, sygn. 39/229, s. 63. Maciejewska w Stowniku biograficznym archiwistów polskich podaje, iż w tym roku objął kierownictwo oddziału akt XIX w., jednak jak wynika z jego akt osobowych, funkcję tę pełnił przynajmniej od 1954 r., gdyż od tego czasu otrzymywał za to dodatek służbowy.

66 AGAD, AZ, sygn. 66, s. 21. 
tomiast w okresie od lipca do września zespół Zarządu Pałaców Cesarskich i Zarządu Gubernatora Płockiego. W tym czasie uporządkował też akta Komisji Rządowej Sprawiedliwości oraz rozpoczął pracę nad aktami różnych urzędów guberni łomżyńskiej ${ }^{67}$.

Uczestniczył również $\mathrm{w}$ pracach zbiorowych nad aktami guberni warszawskiej i kancelarią gubernatora. Warto zauważyć, że niektóre z tych zespołów były przed wojną uporządkowane, ale wydarzenia wojenne wprowadziły w nich chaos, który w połączeniu z brakiem pomocy archiwalnych, które w większości spłonęły, skutkował koniecznością ponownego ich uporządkowania i spisania ${ }^{68}$.

W 1948 r. charakter jego pracy zmienił się, gdyż sprawował on ogólny nadzór i kierował rozpoczętymi wcześniej pracami porządkowymi nad aktami łomżyńskimi i Zarządu Gubernialnego Warszawskiego ${ }^{69}$.

W momencie gdy prace porządkowe w Forcie, mające charakter rekonstrukcyjny lub prowizoryczny, były na ukończeniu i przygotowywano się do przeniesienia akt do siedziby AGAD przy ulicy Długiej, Konarski powrócił do właściwych prac nad porządkowaniem i inwentaryzacją zasobu. W $1950 \mathrm{r}$. zajął się zagadnieniem variów w AGAD i ustaleniem schematu ich organizacji $^{70}$, a przy pomocy praktykantów uporządkował zdezorganizowane akta Komisji Rządowej Wojny ${ }^{71}$.

Rok 1950 to również moment rozpoczęcia prac i badań Konarskiego nad kancelarią austriacką. Prace nad aktami austriackiego Ministerstwa Oświaty z lat 1848-1918 były bardzo wymagające, gdyż ze względu na brak tytułów, konieczne było przeglądanie poszczególnych fascykułów ${ }^{72}$, dlatego też kontynuował je w roku następnym. Pierwsze doświadczenia z tymi aktami zaowocowały referatem Centralne (Ministerialne) akta austriackie w Archiwum Gt[ównym] - charakterystyka i projekt systematyzacji ${ }^{73}$. Na początku $1951 \mathrm{r}$. dokończył wstępne prace inwentaryzacyjne (spisanie kart inwentarzowych)

\footnotetext{
67 Tamże, sygn. 65, Sprawozdania z działalności AGAD za 1945 r., s. 8-12.

68 Tamże, sygn. 66, s. 15.

69 AGAD, AZ, Sprawozdania z działalności AGAD za 1948 r., sygn. 68, s. 41, 114.

70 Tamże, Sprawozdania z działalności AGAD za 1950 r., sygn. 70, s. 24. Praca ta zaowocowała referatem Szczątki zespotów $i$ varia $w$ archiwum, AGAD, AZ, sygn. 70,

71 AGAD, AZ, sygn. 70, s. 157.

72 Tamże, s. 64.

73 AGAD, AZ, sygn. 71, Sprawozdania z działalności AGAD za 1951 r., s. 119.
} s. 166. 
nad zespołem c. k. Ministerium Wyznań i Oświaty ${ }^{74}$. Prace te ostatecznie ukończył i przygotował wstęp do inwentarza w drugim kwartale 1951 r., po czym przystąpił do porządkowania akt c. k. Ministerstwa Kolei Żelaznych ${ }^{75}$. W tym samym roku Konarski zajął się opracowaniem Akt Sekretariatu Stanu Królestwa Polskiego ${ }^{76}$.

Rozpoczęte przez niego prace na variami zaowocowały w 1952 r. zlikwidowaniem działów Nabytki i Varia. Konarski uporządkował te akta, włączając je do odpowiednich zespołów, a jeśli było to niemożliwe, tworzył osobny zbiór lub zespół77. W tymże roku przygotował także wstęp do inwentarza akt Sekretariatu Stanu Królestwa Polskiego i Kancelarii J.C. Mości do spraw Królestw Polskiego ${ }^{78}$.

W 1954 r. dokonał inwentaryzacji kartkowej akt XI korpusu austriackiego $^{79}$, natomiast dwa lata później powrócił do opracowywania akt austriackich, tym razem z okresu okupacyjnego w latach 1915-1918, znanych jako akta Generał-Gubernatora Lubelskiego ${ }^{80}$.

Brak informacji co do wykonywanych przez niego prac inwentaryzacyjnych w 1953 i 1955 r., ale niewykluczone, że zadań takich w ogóle nie wykonywał, gdyż według jego zapisków z dziennika prac archiwalnych widać, że w tym czasie niemalże całkowicie poświęcił się sumaryzowaniu protokołów Rady Administracyjnej ${ }^{81}$.

Pod koniec lat 50. jego prace inwentaryzacyjne nie były już tak intensywne, jak zaraz po wojnie. Ostatnimi pracami widniejącymi w sprawozdaniach AGAD były opracowanie wstępu i skorowidza do zespołu akt Kancelarii Senatora Nowosilcowa w $1960^{82}$ r. oraz reinwentaryzacja akt Zboru Ewangelickiego i porządkowanie i rejestracja variów w aktach Sekretariatu Stanu ${ }^{83}$.

Prace Konarskiego nad zasobem nie ograniczały się jednak wyłącznie do porządkowania konkretnych zespołów. Swoją wiedzę praktyczną przekuwał w ogólne założenia co do opracowania w postaci wytycznych metodycznych.

\footnotetext{
74 Tamże, s. 15.

75 Tamże, s. 74.

76 Tamże, s. 162.

77 AGAD, AZ, sygn. 72, Sprawozdania z działalności AGAD za 1952 r., s. 4.

78 Tamże, s. 13.

79 AGAD, AZ, sygn. 74, Sprawozdanie z działalności AGAD za 1954 r., s. 18.

80 Tamże, sygn. 77, Sprawozdania z działalności AGAD za 1957 r., s. 37.

81 APAN, Materiały Kazimierza Konarskiego, sygn. 5, brak strony.

82 AGAD, AZ, sygn. 80, Sprawozdanie z działalności AGAD za 1960 r., s. 72.

83 AGAD, AZ, sygn. 81, Sprawozdania z działalności AGAD za 1961 r., s. 126.
} 
W 1947 r. wraz z innymi pracownikami archiwum przystąpił do opracowania karty inwentaryzacyjnej dla dokumentów i akt wraz z instrukcją. Natomiast z Adamem Wolffem i Adamem Stebelskim opracował projekt karty inwentaryzacyjnej zespołów wraz z instrukcją ${ }^{84}$. Jako członek komisji normalizacyjnej brał udział w opracowaniu projektu karty chronologicznego katalogu dokumentów ${ }^{85}$.

W sprawozdaniu za 1950 r. Konarski wyszczególnił swój udział w posiedzeniach komisji, która miała za zadanie „ustalenie projektu inwentarza książkowego oraz instrukcji stosowania go w praktyce archiwalnej”. Ukończony projekt miał zostać rozesłany przez NDAP do różnych środowisk archiwalnych dla zebrania o nim opinii ${ }^{86}$. Prace nad schematem inwentarza książkowego były kontynuowane w roku następnym.

Podobnie ewoluowała po wojnie działalność Konarskiego w zakresie opracowania zbiorów kartograficznych. W 1948 r. wraz z Adamem Wolffem i Zofią Krause uczestniczył w pracach komisji kartograficznej, która miała za zadanie opracować instrukcję inwentaryzacyjną dla archiwalnych zbiorów kartograficznych. Szczegółowy zakres prac komisji obejmował opracowanie wzoru księgi inwentarzowej, karty inwentarzowej, karty skorowidzowej i klucza wraz z instrukcjami, a także ustalenie schematu działów projektowanych w przyszłym inwentarzu kartograficznym, wreszcie ogólne wyjaśnienie systemu pracy na tle szczególnej struktury zbioru kartograficznego Archiwum Głównego ${ }^{87}$. Efektem prac komisji było opracowanie ogólnego wyjaśnienia pt. „Organizacja i inwentaryzacja zbioru kartograficznego Archiwum Głównego". Po dokonaniu pewnych zmian wynikłych w związku z przeprowadzoną ankietą, prace nad instrukcją inwentaryzacji archiwalnych zbiorów kartograficznych, prowadzone przez Konarskiego, Wolffa, Leokadię Gołębiowską i Danielę Warecką zostały ukończone w 1951 r. ${ }^{88}$ Efekty prac przedstawił w formie referatu Instrukcja inwentaryzacyjna archiwalnych zbiorów kartograficznych, na zebraniu naukowym AGAD ${ }^{89}$. Konarski nie oderwał się też od pracy praktycznej. Jeszcze w 1950 r. instruował i wykonywał nadzór nad pracą Danieli Wareckiej przy indeksowaniu Zbio-

\footnotetext{
84 Tamże, sygn. 67, s. 10.

85 Tamże, sygn. 68, s. 59.

86 Tamże, sygn. 70, s. 64, 163.

87 Tamże, sygn. 68, s. 49.

88 Tamże, sygn. 71, s. 74.

89 Tamże, s. 119.
} 
ru Kartograficznego AGAD oraz przeprowadził z nią sprawdzenie zawartości czterech tek z mapami i planami ${ }^{90}$.

Jako zastępca dyrektora Konarski brał udział w opracowywaniu archiwalnych normatywów wewnętrznych. Był członkiem komisji normalizacyjnej, która w 1948 r. opracowała schemat indywidualnych kwartalnych sprawozdań personelu oraz ustaliła projekt księgi nabytków i ubytków ${ }^{91}$. W latach 1951-1952 był również członkiem komisji oceny nabytków ${ }^{92}$. Ponadto w 1951 r. opracował projekt statutu Archiwum Głównego i brał udział w komisyjnym ustalaniu definitywnej redakcji tego projektu ${ }^{93}$.

Pomimo tych rozlicznych zadań i funkcji sprawowanych w archiwum, znajdował on jeszcze czas na inne prace wewnątrzarchiwalne. Jego prace nad porządkowaniem zasobu obejmowały niekiedy brakowanie ${ }^{94}$. Do prac, w które zaangażowani byli wszyscy pracownicy archiwum, należało także przeprowadzenie kwerend ${ }^{95}$. Największym tego typu przedsięwzięciem, w którym Konarski brał udział, było poszukiwanie materiałów do dziejów wsi w latach 1951-1953 $3^{96}$.

Ciekawym, ale mało znanym wątkiem w archiwalnej biografii Kazimierza Konarskiego są jego badania w zakresie konserwacji archiwaliów oraz działalność na rzecz zorganizowania w AGAD pracowni konserwacji. W 1947 r. na konferencji archiwistów we Wrocławiu Konarski oraz Włodzimierz Budka wyrazili pogląd, że każde archiwum powinno mieć własną pracownię konserwatorską ${ }^{97}$. Do działań w tym kierunku Konarski przystąpił rok później. W 1948 r. rozpoczął zbieranie literatury dotyczącej konserwacji archiwaliów w związku z planowanym zakupem tejże dla AGAD za pośrednictwem UNESCO. Brał także udział w akcji organizacyjnej stacji badawczej przy Instytucie Przemysłu Chemicznego i konserwatorskiej w Pałacu pod Blachą. Ponadto nawiązał kontakt z Instytutem Chemicznym, przepro-

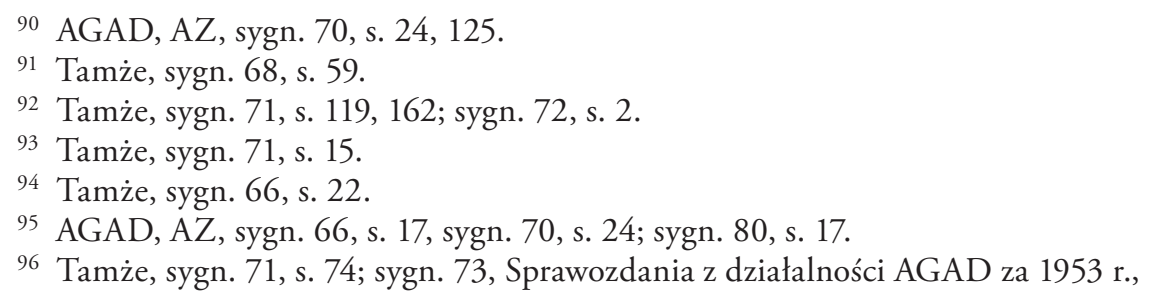
s. 42 .

${ }^{97}$ A. Rybarski, Dziatalność archiwów państwowych w latach 1945-1947, „Archeion” 1948, t. 18, s. 277. 
wadzając z jego biblioteką wymianę danych bibliograficznych w dziedzinie zwalczania pasożytów papieru ${ }^{98}$.

Uczestniczył również w przeprowadzaniu skontrum zasobu. Na konferencji archiwalnej, które miała miejsce 14 grudnia 1950 r. w AGAD, zajął nawet stanowisko w tej sprawie. Jak czytamy w sprawozdaniu: „Konarski, opierając się na doświadczeniach wyniesionych z Archiwum Akt Dawnych, gdzie był zwyczaj przeprowadzania co roku scontrum pewnej części magazynu, co pozwalało odszukać i wyłowić wszystkie akta bez sygnatury, zabłąkane, wystąpił z wnioskiem, by zwyczaj ten zastosować w innych archiwach"99. Natomiast osobiście brał udział w przeprowadzaniu skontrum i systematyzacji akt po przeprowadzce z Pałacu pod Blachą w 1953 r. ${ }^{100}$

Pracami wewnątrzarchiwalnymi, w które szczególnie zaangażowany był Kazimierz Konarski, było opracowywanie pomocy archiwalnych wyższego rzędu. W 1950 r. przy pomocy Wareckiej, Konarski przystąpił do sporządzenia na podstawie egzemplarza kartoteki będącego w posiadaniu NDAP jego kopii przeznaczonej do AGAD, przy czym jak zauważa, „obydwa egzemplarze doraźnie uzupełniłem i poprawiłem”. W momencie sporządzania kartoteka zespołów liczyła 201 pozycji, jednak ostateczne jej sprawdzenie i uzupełnienie miało nastąpić po zakończeni skontrum głównego magazynu AGAD ${ }^{101}$. W tym samym roku sporządził kartotekę zespołów znajdujących się w Forcie im. Sokolnickiego. Ta kartoteka również została wykonana w dwóch egzemplarzach, z których jeden miał pozostać w AGAD, a drugi trafić do NDAP. Rozpoczął też porządkowanie spisanych inwentarzy archiwalnych ${ }^{102}$. W kolejnych latach (1951-1954) Konarski kontynuował prace nad kartoteką zespołów. Przeprowadził rewizję kartoteki, uzupełniając zdezaktualizowane dane w poszczególnych kartach, a także sporządził dublet kartoteki zespołów przeznaczony dla NDAP. Do kartoteki sporządził także spis kart, z uwzględnieniem podziału na grupy. Następnie uzupełnił ją o karty zespołów z terenu guberni płockiej, a także przygotował schemat jej reorganizacji ${ }^{103}$.

W 1952 r. opracował inwentarz inwentarzy zespołów AGAD. Ta pomoc archiwalna swoim zasięgiem miała obejmować wszystkie inwentarzowe po-

\footnotetext{
98 AGAD, AZ, sygn. 68, s. 80, 85.

99 Tamże, sygn. 70, s. 312.

100 Tamże, sygn. 73, s. 11; APAN, Materiały Kazimierza Konarskiego, sygn. 5.

101 AGAD, AZ, sygn. 70, s. 24.

102 Tamże, sygn. 70, s. 64.

103 Tamże, sygn. 71, s. 119, 162; sygn. 72, s. 3, 136; sygn. 73, s. 12; sygn. 74, s. 5.
} 
moce archiwalne stworzone do zespołów, również te, które opracowane zostały, zanim zespół trafił do archiwum. Opracował on inwentarz ciągły oraz kartotekę inwentarzy, obejmującą około 1600 pozycji ${ }^{104}$. Syntetyczne ujęcie tego zagadnienia dał w referacie Inwentarz inwentarzy wygłoszonym na zebraniu naukowym AGAD 21 kwietnia 1952 r. ${ }^{105}$

Kolejne lata w zakresie pomocy archiwalnych zdominowane były przez opracowywanie Sumariusza Protokołów Rady Administracyjnej. Pod koniec swej etatowej pracy w archiwum Konarski brał udział w pracach nad przygotowaniem przewodnika po zasobie AGAD. W 1960 r. przeprowadził badania szeregu wydawnictw i czasopism historycznych dla przygotowania bibliografii do pracy nad przewodnikiem. W roku następnym brał udział w systematyzacji tej bibliografii oraz opracowywaniu schematu układu i projektu struktury wydawnictwa ${ }^{106}$.

Mało natomiast czasu poświęcał Konarski na popularyzację zasobu. Jedynym jego przedsięwzięciem w tym zakresie było zorganizowanie wystawy Przesztość Warszawy $w$ dokumencie oraz prace nad sporządzeniem jej katalo$\mathrm{gu}^{107}$. Można także w tym miejscu wspomnieć o popularyzowaniu przez niego zasobu AGAD przez oprowadzanie wycieczek studentów po archiwum ${ }^{108}$. Jak widać, praca publiczna archiwów była zawsze dla Konarskiego zajęciem marginalnym.

Kontynuacją przedwojennych zainteresowań była działalność Konarskiego w zakresie kształcenia archiwistów. Już w 1948 r. wraz z innymi pracownikami AGAD (Stebelski, Wolff, Jadwiga Karwasińska) wystosował memoriał w sprawie powołania studium archiwalnego ${ }^{109}$. W tym samym roku poproszono go na zebraniu Sekcji Archiwalnej Warszawskiego Koła Związku Bibliotekarzy i Archiwistów Polskich, jako kierownika organizowanych przed wojną kursów archiwalnych, o współpracę przy opracowaniu programu kursu archiwalnego dla kierowników składnic akt. Jak pisała Jadwiga Jankowska w sprawozdaniu z działalności sekcji: „Program ten zreferował dyr. Konarski na konferencji, zwołanej 7 czerwca w porozumieniu z Wydziałem Archiwów

\footnotetext{
104 Tamże, sygn. 72, s. 136.

105 Tamże, s. 17.

106 AGAD, AZ, sygn. 80, s. 17; sygn. 81, s. 23, 124.

107 Tamże, sygn. 69, s. 103.

108 Tamże, sygn. 74, s. 36.

109 Tamże, sygn. 68, s. 59.
} 
Państwowych Ministerstwa Oświaty"110. Program obejmował zagadnienia organizacji służby archiwalnej, ustroju władz i urzędów polskich oraz szeroko pojęte zagadnienia kancelaryjne, obejmujące historię rozwoju kancelarii, organizację kancelarii i przepisy kancelaryjne, jak również problematykę wykazów akt, organizacji składnic akt i brakowania akt ${ }^{111}$. Konarski nie tylko brał udział w układaniu programu kursów, ale pozostał też czynnym wykładowcą. W 1949 r. prowadził wykłady na kursie archiwalnym w Otwocku i w Warszawie, natomiast w 1950 r. wykład Podstawowe zagadnienia archiwalne na kursie dla kierowników składnic akt, organizowanym przez KC PZPR oraz był prelegentem na kursie archiwalnym w Jarocinie ${ }^{112}$. Opracowanie programu kursów nie było jedynym tego typu przedsięwzięciem, w jakim Konarski brał udział. Jak sam pisał: „Współdziałałem w zespołowym opracowaniu programu studiów w zakresie archiwistyki na III roku nauczania historii w Uniwersytecie Warszawskim"113. Wraz z innymi pracownikami archiwum uczestniczył $\mathrm{w}$ doszkalaniu młodszego personelu archiwalnego. W 1949 r. zorganizowano w AGAD sześć tygodniowych posiedzeń dla zapoznania młodszego personelu z archiwaliami poszczególnych działów archiwum. Jednym z wykładowców był właśnie Konarski ${ }^{114}$. Jednak zdecydowanie najwięcej czasu w zakresie kształcenia poświecił na szkolenie praktykantów stypendystów (1950-1953) ${ }^{115}$.W sprawozdaniu za 1951 r. widnieje również informacja, iż Konarski przygotowywał kursy kartograficzne - archiwalny i biblioteczny ${ }^{116}$. Brak jednak szerszych informacji, jaki był to kurs.

Działalność Kazimierza Konarskiego, podobnie jak w okresie przedwojennym, nie zamykała się w murach archiwum. Dalej czynnie działał w Towarzystwie Miłośników Historii w Warszawie, a następnie również w Sekcji Archiwalnej Warszawskiego Koła Związku Bibliotekarzy i Archiwistów Polskich. Często wygłaszał tam referaty będące wynikiem jego działalności archiwalnej, jak chociażby Dziat variów w archiwum czy Archiwistyka i jej części sktadowe. Z myślą o wystąpieniu na Kongresie Nauki, w 1950 r. przygotował

110 A. Rybarski, dz. cyt., s. 288.

111 Tamże, s. 288-289.

112 AGAD, AZ, sygn. 69, Sprawozdania z działalności AGAD za 1949 r., s. 23, 150; sygn. 70, s. 24, 163 (nie ma pewności, czy to nie był ten sam kurs).

113 AGAD, AZ, sygn. 71, s. 16.

114 Tamże, sygn. 69, s. 145.

115 Tamże, sygn. 70, s. 163; sygn. 71, s. 16, 74; sygn. 72, s. 137, 197; sygn. 73, s. 32.

116 Tamże, sygn. 71, s. 162. 
tezy referatu Analiza aktu jako podstawa do stworzenia nauki o akcie, który ostatecznie wygłosił na Konferencji Archiwalno-Bibliotecznej pod zmienionym nieco tytułem Analiza aktu jako podstawa archiwistyki ${ }^{117}$. Na zebraniach Sekcji Archiwalnej Warszawskiego Koła Związku Bibliotekarzy i Archiwistów Polskich światło dzienne ujrzały efekty jego dużych powojennych przedsięwzięć archiwalnych. Pierwszym z nich była praca nad reedycją podręcznika archiwalnego. Prace te rozpoczął już w 1946 r. ${ }^{118} \mathrm{Na}$ posiedzeniu Sekcji Archiwalnej 23 kwietnia 1947 r. wystąpił z referatem, w którym zapowiadał konieczność reedycji podręcznika archiwistyki polskiej i przedstawił konspekt nowego podręcznika. Podręcznik miał być przygotowany we współpracy z Adamem Stebelskim, dzięki czemu jego zakres miał być rozszerzony na archiwa średniowieczne, za to pomijał zupełnie archiwoznawstwo. Podręcznik miał się składać z czterech części, jako pierwsza widniała Archiwistyka ogólna (terminy archiwalne, kategorie archiwów, stanowisko prawne, zarys archiwów w Polsce i tradycje archiwalne). Kolejny dział to Wewnętrzne zagadnienia archiwalne (geneza i ewolucja dokumentu, prace archiwalne, gmach archiwalny, prawa i obowiązki archiwisty). Jako trzeci punkt wymienił $Z a-$ rząd archiwami (inicjatywa prawodawcza, propaganda, sieć archiwalna, szkolenia archiwistów, oddziaływanie na archiwa bieżące, opieka nad niepaństwowymi). Podręcznik zamykać miały Uzupetnienia i aneksy (przepisy i ustawy archiwalne, bibliografia, słownik terminów archiwalnych, wzory inwentarzy i skorowidzów). W dyskusji nad przedstawionym przez Konarskiego projektem podręcznika przeważała opinia, że powinien mieć on w jak największym stopniu charakter praktyczny ${ }^{119}$.

Jak wynika ze sprawozdań AGAD i raptularza Konarskiego, jeszcze tego samego roku przystąpił do intensywnych prac nad podręcznikiem i napisał rozdziały Zespót jako wytwór działalności urzędu, Pomocnicze księgi archiwalne, Brakowanie akt. Jako że w podręczniku miały być również poruszone kwestie konserwacji, zapoznał się on z literaturą (przeważnie włoską) na ten temat $^{120}$. W 1948 r. jego prace nad podręcznikiem ograniczały się do zbiera-

117 Tamże, sygn. 70, s 24, 125, 166; sygn. 71, s. 16.

118 Tamże, sygn. 66, s 14.

119 J. Jankowska, Dziatalność Sekcji Archiwalnej Warszawskiego Kota Związku Bibliotekarzy i Archiwistów Polskich w Warszawie w 1947 r., „Archeion” 1948, t. 17, s. 230.

${ }^{120}$ AGAD, AZ, sygn. 67, s. 74, 88; APAN, Materiały Kazimierza Konarskiego, sygn. 5 . 
nia literatury ${ }^{121}$. Na tym jednak kończą się informacje co do jego prac nad podręcznikiem archiwalnym. W 1949 r. widnieje jedynie informacja o opracowaniu przez niego artykułu do „Archeionu” pt. Podstawowe zasady archiwistyki ${ }^{122}$.

Równocześnie z pracami nad podręcznikiem, Konarski rozpoczął swe powojenne badania w zakresie terminologii, które zaowocowały wydaniem pierwszego Polskiego stownika archiwalnego. Prace nad słownikiem rozpoczęte zostały w 1947 r. powołaniem przy Sekcji Archiwalnej Koła Warszawskiego Związku Bibliotekarzy i Archiwistów Polskich komisji terminologicznej w składzie Kazimierz Konarski, Aleksy Bachulski i Adam Wolff. W komisji pełnił on funkcję przewodniczącego, i jednocześnie sekretarza. Konarski 21 października 1947 r. wygłosił referat Zagadnienia terminologii archiwalnej, w którym ukazywał konieczność badań nad terminologią i jej ujednostajniania $^{123}$. Prace nad słownikiem postępowały szybko. Jak pisał w sprawozdaniu za 1947 r. (datowanym na 8 stycznia 1948 r.), „Zebrane (około tysiąca) terminy zostały usystematyzowane w dwóch kartotekach: alfabetycznej i rzeczowej, przebrakowane i w dużym procencie zaopatrzone już w definicje. Terminy zasadnicze, kluczowe, są wybrane i będą kolejno omawiane na posiedzeniach sekcji archiwalnej T.M.H.”124. Sam przygotował parę takich omówień, wygłaszając w 1948 r. referaty Zespót, zasób i terminy pokrewne oraz Klasyfikacja akt i terminy pokrewne $e^{125}$.

W tymże roku komisja zaopatrzyła większość terminów w definicje i ukończyła pierwsze czytanie słownika. W następnym roku prowadzono badania lingwistyczne w związku z tłumaczeniem terminów polskich na języki obce, przeprowadzono korektę rzeczową słownika oraz przygotowano go do powielania celem przesłania ośrodkom archiwalnym i bibliotecznym do oceny. Po wprowadzeniu do słownika zmian, wynikłych z przeprowadzonej ankiety na Konferencji dyrektorów w Otwocku, i przyjęciu przez Komisję terminologiczną tych poprawek, w 1951 r. opracowano definitywną redakcję

\footnotetext{
121 AGAD, AZ, sygn. 68, s. 42.

122 AGAD, AZ, sygn. 69, s. 150.

123 J. Jankowska, dz. cyt., s. 228-229, 231; AGAD, AZ, sygn. 67, s. 74.

124 AGAD, AZ, sygn. 67, s. 74.

125 Tamże, sygn. 68, s. 28, 87.
} 
projektu słownika ${ }^{126}$. Mimo że słownik datowany jest na 1952 r., ukazał się on rok później ${ }^{127}$.

Warto zauważyć, że Konarski pod koniec swej zawodowej działalności archiwalnej powrócił do badań nad terminologią archiwalną. W $1961 \mathrm{r}$. opublikował w „Archeionie” artykuł Podjecie pracy nad nowa edycja polskiego stownika archiwalnego i osobiście tę działalność podjął. W sprawozdaniu AGAD za 1961 r., w punkcie dotyczącym słownika archiwalnego czytamy: „Gromadzono karty terminologiczne nadesłane przez archiwa w liczbie ok. 1200. Przerobiono wydawnictwa J. Kozłowski i Meisner - Loesch. Pracę tę prowadził wyłącznie prof. Konarski bez udziału pracowników innych oddziałów"128.

Jak da się zauważyć, wszystkie wymienione prace zakończone zostały na początku lat 50. Wtedy pierwsze miejsce w archiwalnej działalności Konarskiego zajął do końca jego zawodowej aktywności Sumariusz Protokołów Rady Administracyjnej Królestwa Polskiego z lat 1815-1867. Konarski był pomysłodawcą tego przedsięwzięcia, a nawet - jak zauważa Piotr Bańkowski - „mózgiem, duszą i sercem” tej pracy ${ }^{129}$. W 1952 r. rozpoczął prace wstępne nad sumariuszem, ustalając ze Stebelskim metody pracy ${ }^{130}$. Na sporządzanie kart sumariusza poświęcał zdecydowanie najwięcej czasu wśród swych prac archiwalnych ${ }^{131}$. W sprawozdaniu z prac oddziału III w 1954 r. dowiadujemy się, że początkowe prace sumaryzacyjne prowadził sam, następnie do pomocy przydzielona została mu Franciszka Ramotowska, później również inni pracownicy, jednak ze względu na ich pozostałe obowiązki służbowe, prace nad sumariuszem prowadziły jednocześnie maksymalnie dwie osoby, w tym zawsze Konarski. Do sumariusza sporządzono karty sumariuszowe rzeczowe, karty sumariuszowe imienne, karty indeksowe imienne oraz karty indeksowe geograficzne. Karty narastały chronologicznie, ale przystąpiono do ich wstępnej systematyzacji, wykorzystując trzy sposoby: alfabetyczny, resortowo-logiczny i mieszany (podział na resorty, a w obrębie resortu - alfabetyczny).

126 AGAD, AZ, sygn. 68, s. 42, 59; sygn. 69, s. 59, 97, 154; sygn. 70, s. 24; sygn. 71, s. 54 .

127 APAN, Materiały Kazimierza Konarskiego, sygn. 5; K. Konarski, Dalekie a bliskie, s. 332.

128 AGAD, AZ, sygn. 81, s. 23.

129 P. Bańkowski, Kazimierz Bogdan Konarski (27 maja 1886 - 3 listopada 1972), „Archeion” 1973, t. 59, 1973, s. 351.

130 AGAD, AZ, sygn. 72, s. 12.

131 Tamże, sygn. 73, s. 20; sygn. 74, s. 5. 
Sposoby układu oraz ogólne przemyślenia na temat sumariuszy i indeksów przedstawił w referatach wygłoszonych na zebraniach naukowych AGAD w 1954 r.: Indeks archiwalny i Sumariusz Protokołów Rady Administracyjnej ${ }^{132}$.

Prace nad sumariuszem, polegające na tworzeniu kart, ich systematyzacji i tworzeniu skorowidzów, kontynuowane w latach kolejnych, zdominowały działalność oddziału III AGAD w 1958 r. w związku z przygotowaniem do druku tomu I sumariusza. Równolegle kontynuowano prace nad sumaryzowaniem dalszych ksiąg protokołów ${ }^{133}$. Prace nad sumariuszem prowadził do końca swej pracy w archiwum, a w kontynuowaniu ich nie przeszkodziło mu przejście na emeryturę. Jak zauważył Bańkowski: „Przy dalszej pracy nad tą benedyktyńską regestacją zaskoczyła Konarskiego śmierć"134.

Archiwalne prace Kazimierza Konarskiego zmierzały w różnych kierunkach, jednak głównym torem jego działalności była praca nad zasobem archiwalnym. Zajmował się on przede wszystkim opracowaniem, i to opracowaniem zasobu, co należy podkreślić, wyłącznie dziewiętnastowiecznego. Wynikało to zarówno z jego zainteresowań historycznych, jak i z charakteru instytucji, w jakiej przyszło mu pracować. Praca nad tymi aktami pozwoliła poznać mu mechanizmy funkcjonowania kancelarii polskiej (opartej na wzorach pruskich), jednak znakomita większość akt, z którymi stykał się Konarski, została wytworzona przez tzw. kancelarię rosyjską. Celem maksymalnego uprzystępnienia użytkownikom tych akt przystąpił do opracowywania referatów na temat kancelarii, registratury i archiwum danego urzędu, które stały się zaczątkiem późniejszych wstępów do inwentarza. W ramach tych prac tworzył też skorowidze do zespołów. Specyficzny charakter tych akt $\mathrm{z}$ ich rocznymi uwarstwowieniami wpłynął na pomysł stworzenia pomocy archiwalnej grupującej wszystkie kancelaryjne spisy akt, jaką był inwentarz inwentarzy. Przedłużeniem prac nad poszczególnymi zespołami była chęć ich naukowej organizacji. Stąd wychodziły pomysły różnych pomocy ponadzespołowych, jak kartoteka zespołów, inwentarz generalny, inwentarz topograficzny. Po wojnie Konarski rozszerzył swoje badania na kancelarię austriacką. Jednak istotne jest, że jego działalność ewoluowała w kierunku uogólniania swych praktycznych doświadczeń, czego wynikiem była praca nad wytycznymi metodycznymi. Uporządkował też w pewnym stopniu swe rozmyślania

132 Tamże, sygn. 74, s. 7, 40, 86.

133 Tamże, sygn. 78, s. 10,39, 51.

134 P. Bańkowski, dz. cyt., s. 351. 
w zakresie pomocy archiwalnych. Po wojnie skupił się na konsekwentnym uzupełnianiu i organizowaniu kartoteki zespołów oraz tworzeniu pomocy wyższego rzędu z sumariuszem na czele.

Prace nad zasobem to także zaczątki metodyki opracowania dokumentacji nieaktowej. Jego działalność w zakresie opracowania zasobu kartograficznego AAD zaowocowała po wojnie, podobnie jak w przypadku dokumentacji aktowej, wydaniem wytycznych metodycznych.

Mało natomiast miejsca w swej działalności poświęcił na zagadnienia związane z selekcją. Właściwie ograniczały się one do doświadczeń związanych z brakowaniem opracowanych przez niego zespołów przed- oraz powojennych. W małym stopniu interesowały go także zagadnienia udostępniania i popularyzacji archiwaliów.

Wieloletnie kierownictwo placówkami archiwalnymi pozwoliło mu doskonale poznać organizację archiwów, jak również mechanizmy funkcjonowania służby archiwalnej.

Bez wątpienia miał duże zasługi na polu kształcenia kadr archiwalnych. Mimo niezrealizowanych wielokrotnych postulatów stworzenia szkoły archiwalnej, konsekwentnie realizował politykę kształcenia w zakresie archiwistyki, przed wojną w postaci kursów archiwalnych, a w okresie powojennym przede wszystkim przez szkolenie stypendystów praktykantów (instytucji znanej już w okresie międzywojennym).

W dużym stopniu przyczynił się również do ujednostajnienia polskiej terminologii archiwalnej. Mimo że pierwsze próby mogły nie być doskonałe, powojenny efekt $\mathrm{w}$ postaci słownika archiwalnego był bez wątpienia dużym osiągnięciem.

\section{Przedmiot, zakres i PODZIAł ARCHIWistyKi W UJĘCIU KaZimierza KonarsKiego}

Wielokrotnie przywoływane słowa Kazimierza Konarskiego o tym, że archiwistyka polska jest w stanie płynnym, są dobrym punktem wyjścia do badania jego rozważań i wniosków na temat tej dyscypliny wiedzy ${ }^{135}$. Archiwistyka polska w ujęciu Konarskiego ma trzy podstawowe braki - metodologii, terminologii i ustalonej praktyki. Może to oznaczać, że widział archiwistykę sze-

135 Por. B. Ryszewski, O badaniach, s. 174; Z. Chmielewski, Polska myśl archiwalna, s. 71-72. 
rzej niż naukę, włączając w jej zakres również praktyczną działalność archiwów $^{136}$. Braku teoretycznych uogólnień w zakresie archiwistyki polskiej nie można do końca zastąpić opracowaniami zagranicznymi, gdyż zdaniem Konarskiego „wzory obce służyć mogą w tym tylko stopniu, w jakim archiwistyka jednego kraju może być przeniesiona na grunt innego ustroju archiwalnego. W praktyce sprowadza się to do szeregu zasadniczych założeń, których rozwinięcie, a przede wszystkim uzasadnienie przy pomocy przykładów musi uzyskać wyraźnie polskie już lokalne zabarwienie"137. Dlatego też nie można przeszczepić przedmiotu archiwistyki i zakresu ${ }^{138}$, należy stworzyć ją samemu ${ }^{139}$. Zauważa duże znaczenie praktyki w działalności archiwalnej. Pisze wyraźnie, że aby ustalić zręby archiwistyki, zadania należy podzielić na praktyczne i teoretyczne. Jeśliby zadania te rozciągnąć na jego widzenie archiwistyki, dzieliłaby się ona na teorię i praktykę. Teoria obejmowałaby zagadnienia terminologii i metodologii, czyli elementy, które musi posiadać nauka, by została uznana za samodzielną. Natomiast do praktyki zalicza problem scalenia archiwaliów, kształcenia archiwistów, ale też brakowania (szkartowania), nie widząc w nim problemu teoretycznego, a jedynie czysto techniczną czynnośćc ${ }^{140}$.

Za najważniejszy element teoretyczny archiwistyki uważa ustalenie zasady proweniencji z wynikającym z niej zagadnieniem zespołu archiwalnego $^{141}$. Problematyka ta stanowi jednak w działalności Kazimierza Konarskiego kluczowe miejsce, dlatego w pracy tej będzie przedmiotem odrębnego omówienia.

Opisanie przez Konarskiego zespołu jako obiektu archiwalnego pozwala wysnuć wnioski na temat miejsca archiwistyki wśród innych nauk. Jak zauważa Konarski, „o ile w dyplomatyce średniowiecznej dzieje kancelarii odgrywają poważną rolę, o tyle w nowożytnej historii i nowożytnej archiwistyce kancelaria urzędu jest z reguły pomijana zupełnie. Pomijana niesłusznie. Jałowy ten pozornie i jednostajny temat w rzeczywistości nie jest ani jałowy,

136 Podobnie archiwistykę będzie widział później Aleksander Gieysztor i za nim Józef Szymański. A. Gieysztor, Zarys nauk pomocniczych historii, t. 1, Warszawa 1948; J. Szymański, Nauki pomocnicze historii, Lublin 1968.

137 K. Konarski, Z zagadnień nowożytnej archiwistyki polskiej, „Archeion” 1927, t. 1, s. $106-107$.

138 Tamże, s. 107.

139 Tamże.

140 Tamże.

141 Tamże, s. 108. 
ani tym bardziej jednostajny, daje bowiem historykowi klucz do zrozumienia merytorycznego ustroju urzędów, archiwiście zaś możność zorientowania się w spuściźnie akt i rozwiązania całego szeregu zagadek. Nowożytna archiwistyka nie może się obejść bez stworzenia nowożytnej dyplomatyki"142. Zatem badania archiwalne mają na względzie potrzeby historyków, ale żeby dobrze odpowiedzieć na ich zapotrzebowanie, w orbitę swych zainteresowań muszą wciągnąć badania dyplomatyczne.

Warto dodać, iż takie centralne umieszczenie w pracy problemu zespołu archiwalnego może sugerować, że Konarski traktował to zagadnienie jako przedmiot badań archiwistyki, natomiast zakresem byłoby w tym przypadku wszystko to, co dzieje się z zespołem przed jego trafieniem do archiwum i już w samej instytucji.

Pogląd Konarskiego na archiwistykę można odnaleźć nie tylko bezpośrednio w jego słowach, ale także wysnuć z ogólnej analizy jego tekstów. W swoim dziele zatytułowanym Nowożytna archiwistyka polska i jej zadania bezpośredniego zdania na temat archiwistyki jako nauki nie wyraził, jednak wiele o jego spojrzeniu mówi układ tej pracy. Otwiera ją omówienie zagadnienia archiwów i ich charakterystyka ogólna. Omówienie to jest o tyle ważne, że są one miejscem przechowywania zespołów archiwalnych (w tym też rozdziale przywołuje definicję zespołu archiwalnego). Podaje też zadania i cele archiwów, a wśród nich bierne, czyli przechowywanie i ochrona archiwaliów przed zniszczeniem, oraz czynne, czyli udostępnianie zainteresowanym. Kolejne dwa rozdziały to omówienie zespołu archiwalnego najpierw jako wytworu działalności urzędu, a następnie jako obiektu archiwalnego. Następne zagadnienia to klasyfikacja akt, inwentaryzacja i skorowidz, czyli to, co robi się z zespołem, kiedy jest on już w archiwum. A wszystko to zamyka zagadnienie konserwacji akt, w której oprócz dzisiejszego rozumienia konserwacji, znajdują się także zagadnienia przechowywania, gromadzenia i brakowania akt. $\mathrm{Z}$ przedstawionego zarysu widać, że w centrum zainteresowania autor stawia zespół archiwalny.

Pewien jego pogląd na archiwistykę i działalność archiwalną można zauważyć, przyglądając się opisowi metody rekonstrukcji układu akt. Jest to przede wszystkim pogląd na zasadę proweniencji, ale samo widzenie archiwistyki nie jest tu bez znaczenia. Po wymienieniu kilku możliwych sposobów układu stwierdza Konarski, że system organiczny jest zbiorem systemów - ile

142 Tamże, s. 120. 
układów, tyle systemów odtwarzania, system ten nie tylko nie przeciwstawia się poprzednim, ale mieści je w sobie. Każdy zespół może być porządkowany tylko według metody, przy pomocy której był tworzony, archiwista ma tę metodę poznać, zrozumieć i wcielić w życie przy porządkowaniu akt. Jego zadaniem jest odtworzenie pierwotnego porządku, pierwotnej organizacji zespołu archiwalnego. Nie daje zatem Konarski jasnej metody, drogi postępowania, każe każdy zespół traktować indywidualnie, podchodzić do niego bez z góry powziętych założeń ${ }^{143}$. Oznacza to, że - mimo iż zasadę proweniencji uznaje za kategoryczną - jest ona tylko wskaźnikiem, nie daje wyraźnej odpowiedzi, jak należy rekonstruować zespół. Konarski tej odpowiedzi również nie daje, stwierdzając jedynie, że odpowiedź tę mogą dać tylko akta. Odsuwa się więc od wysuwania pewnych teoretycznych uogólnień, kategorycznych założeń, gdyż „kardynalną cechą archiwistyki jest kompromisowość, a więc liczenie się z warunkami realnymi. Nie ma w niej ani jednego bodaj dogmatu, który można byłoby wcielić w życie w całej jego rozciągłości; archiwista w swej pracy nieustannie styka się z koniecznością czynienia odstępstw z teorii w imię praktyki życia archiwalnego" 144 . Widać zatem, że teoria, owszem, jest ważna, jednak wyłącznie w granicach pewnych ogólnych zrębów, których przestrzeganie jest konieczne, jednak to potrzeby praktyki powinny regulować życie archiwalne ${ }^{145}$. Widzi zatem możliwość niecałkowitej realizacji metody odtworzenia układu pierwotnego, nie ma więc kategorycznego spojrzenia na główną jego zdaniem zasadę archiwistyki, czyli zasadę proweniencji.

Utrzymując się w nurcie archiwistyki jako nauki stosowanej, bardzo praktycznej, opisuje zadania, jakie stoją przed archiwami, stawiając jednocześnie zadania archiwistyce, jako nauce mającej wspierać działania archiwów. Główne problemy to przejmowanie akt z urzędów, opracowanie przepisów i regulaminów wewnętrznych, konieczność wprowadzenia przepisów o brakowaniu akt. Kontynuuje swoje wcześniejsze rozważania także w zakresie konieczności ustalenia słownictwa archiwalnego i potrzeby kształcenia archiwistów ${ }^{146}$.

Jednak za kluczowe w działalności archiwów uważa zagadnienie prac wewnętrznych. Dał temu wyraz, recenzując dział archiwalny w czasopiśmie

\footnotetext{
143 K. Konarski, Nowożytna archiwistyka, s. 66-67.

144 Tamże, s. 66.

145 Tamże, s. 69.

146 K. Konarski, W. Łopaciński, Reorganizacja archiwów państwowych, [w:] Pamiętnik V Powszechnego Zjazdu Historyków Polskich w Warszawie, red. K. Tyszkowski, Lwów
} 1930, s. 460. 
„Ateneum Kapłańskie”. Stwierdził tam, że „w dzisiejszych czasach wychodzenia z chaosu, porządkowania i rejestracji posiadanych zasobów archiwalnych zagadnienia metodologiczne i organizacyjne muszą nie tylko wysunąć się na pierwszy plan [...], ale muszą na tym pierwszym planie nadal pozostawać i wciąż o sobie przypominać"147. Dodał, że szczególną uwagę powinno się zwrócić na zagadnienia inwentaryzacji. Jest to kontynuacja jego wcześniejszej myśli, że największą wagę trzeba przywiązywać do prac wewnętrznych i to powinno być zaakcentowane w piśmiennictwie.

Jak wiadomo, Kazimierz Konarski po wojnie pracował nad nowym podręcznikiem archiwistyki, który ostatecznie nie został wydany, jednak zachował się jego szczegółowy konspekt, który bez wątpienia mówi wiele o poglądzie autora na archiwistykę. Podręcznik miał być zatytułowany Archiwistyka polska. Już samo dookreślenie „polska” świadczy o kontynuacji myśli, że archiwistyka jako nauka stosowana nie jest uniwersalna i musi posiadać swoje lokalne zabarwienie i taki charakter ma właśnie jego praca.

Podzielona ona została na cztery części. Pierwsza to charakterystyka ogólna zagadnień archiwalnych, w której Konarski zdefiniować miał pojęcie archiwum, cele archiwów i ich rodzaje. Ponadto część ta obejmowała również archiwoznawstwo (Zarys historii archiwów w Polsce) ${ }^{148}$. Druga część, najobszerniejsza, obejmowała zagadnienia metodyczne. Poprzedzało je historyczne ujęcie powstawania dokumentów, a następnie zespołów archiwalnych i przywołanie definicji zespołu i zasobu (w rozumieniu zbioru) oraz opisanie systemów kancelaryjnych ${ }^{149}$. Do właściwych zagadnień metodycznych (Prace archiwalne) zaliczał klasyfikację akt i jej metody, porządkowanie (względnie rekonstrukcję) zespołów, inwentaryzację i indeksowanie akt, porządkowanie i inwentaryzację archiwaliów prywatnych, rewizje i skontra zespołów, konserwację akt, brakowanie akt, kompletowanie biblioteki archiwalnej, udostępnianie akt, kwerendy archiwalne, wydawnictwa archiwum, wystawy i pokazy archiwalne, dydaktykę i atmosferę naukową ${ }^{150}$. Nie można pozbyć się wraże-

${ }^{147}$ K. Konarski, rec. $Z$ archiwistyki kościelnej, Ateneum Kaptańskie, t. 36, 1935 , s. 23-533, „Archeion” 1937-1938, t. 15, s. 130.

148 Tenże, „Archiwistyka polska”. Konspekt pracy, APAN, Materiały Kazimierza Konarskiego, sygn. 2, „Archiwistyka polska”, „Analiza aktu jako podstawa archiwistyki”, „O archiwiście słów kilkoro”. Konspekt pracy, referat przygotowany na I Kongres Nauki Polskiej, artykut, k. 1.

149 Tamże, k. 2.

150 Tamże, k. 3-4. 
nia, iż w zakresie metodyki archiwalnej umieścił wszystkie czynności, jakie wykonuje się w archiwum, przynajmniej wszystkie te, z którymi w własnej pracy archiwalnej miał styczność.

Część drugą rozszerzył ponadto o opisanie pomocniczego aparatu archiwalnego, do którego zaliczył pomoce ogólne obejmujące cały zasób, pomoce inwentaryzacyjne oraz pomoce kontrolne. Poruszył także zagadnienia gmachów i technicznych warunków pracy archiwalnej oraz problematykę zawodu archiwisty ${ }^{151}$.

Część trzecia Zarząd zwierzchni archiwów. Zadania i środki dziatania obejmowała zagadnienia prawne działalności archiwów, problem organizacji sieci archiwalnej, rewindykacji, organizacji samych archiwów i kontroli nad nimi, ale także problem szkolenia archiwistów, działalności wydawniczej oraz nadzór nad archiwami (Oddziatywanie na prace kancelaryj w urzędach czynnych oraz Opieka nad archiwaliami niepaństwowymi i bezpańskimi $)^{152}$. Zakres archiwistyki wyznaczony takimi zadaniami wydaje się ogromny, być może jednak wrażenie to jest wynikiem pewnego nieuporządkowania wymienionych zagadnien ${ }^{153}$.

Ostatnia część, Zamknięcie, uzupetnienia i aneksy, miała zawierać zakończenie, w którym opisana zostałaby ówczesna rzeczywistość archiwalna i postulaty na przyszłość.

Nowe zagadnienia archiwalne po II wojnie światowej Konarski nakreślił w artykule zatytułowanym nomen omen Nowe zadania polskiej archiwisty$k i$. Jakie zatem są to zadania? A może właściwsze byłoby pytanie: co spowodowało powstanie nowych zadań polskiej archiwistyki? Przyczyną ich ujawnienia się były straty wojenne, jakie poniosły polskie archiwa. Straty, które przyniosła wojna i barbarzyństwo niemieckie, stawiają przed archiwistami bardzo ważne zadanie, „zapełnienia choćby częściowe dokonanych luk i spustoszeń" ${ }^{\prime 154}$. Ma to się odbywać na kilka sposobów, m.in. przez rewindykację, uzupełnienie archiwów o materiały znajdujące się w zbiorach prywatnych czy poszukiwanie tzw. materiałów zastępczych, zwrócenie uwagi na materiały dotychczas postrzegane jako te o mniejszej wartości i wydobycie z nich informacji, zwrócenie także uwagi na szczątki zespołów. W ten sposób zasadniczo

151 Tamże, k. 4-6.

152 Tamże, k. 6-7.

153 Zob. Aneks, s. 96-100.

154 K. Konarski, Nowe zadania polskiej archiwistyki, „Archeion” 1948, t. 17, s. 23. 
zakres archiwistyki się nie zmienia, inny jest jednak punkt ciężkości, który został położony na poszczególne funkcje i zadania archiwów.

Jednak zniszczenia wojenne mogą zdaniem Konarskiego przeformułować archiwistykę w większym stopniu, niż mogłoby się to wydawać. Jak zauważa: „Jeśli takich drogocennych szczątków okaże się więcej w innych zespołach, w takim razie czekać będą archiwistykę polską nowe zadania, nowe kryteria i nowe metody klasyfikacyjne. Wobec takich akt zblednie dogmat współczesnej archiwistyki - zespół akt. Miejsce jego zajmie w danym wypadku zlepek szczątków usystematyzowany raczej rzeczowo, po bibliotecznemu czy zgoła średniowiecznemu, jak rzadkie druki czy dyplomy pergaminowe. Związek organiczny ustąpi miejsca tematycznemu, wytworzą się gniazda czy rezerwaty akt różnego pochodzenia tej samej za to lub pokrewnej treści” ${ }^{155}$. W ten sposób zniszczenia wojenne zachwiały wyobrażenie Konarskiego na temat archiwistyki. On, gorący orędownik zasady proweniencji i jej centrum, jakim jest zespół archiwalny, zgadza się na rzeczowe grupowanie archiwaliów, w celu wyciągnięcia wartościowych materiałów i służenia nimi nauce historycznej.

Wydaje się, że dojrzały, a przynajmniej usystematyzowany wykład na temat archiwistyki dał Konarski w Podstawowych zasadach archiwistyki z 1951 r. Już w pierwszych zdaniach wyjaśnia, czym jest archiwistyka i jaki jest jej zakres. Pojęcie archiwistyki poprzedza jednak wyjaśnieniem, czym są akta. „Akta - archiwalia - są najstarszym pomnikiem kultury, zrodzonym w dobie, w której myśl ludzka poczęła szukać sposobów utrwalenia się w piśmie - na cegiełce, skorupce czy papirusie. Natomiast archiwistyka, czyli nauka o aktach, ich systematyzacji, sposobach przechowywania, konserwacji, udostępnianiu itd., jest dyscypliną stosunkowo młodą" ${ }^{156}$. Zatem przedmiotem archiwistyki są akta i to, co się z nimi robi w archiwach, jednak to zespół archiwalny pozostaje $\mathrm{w}$ centrum zainteresowania badań archiwalnych, gdyż „kamieniem węgielnym tej nauki jest wykrystalizowanie się pojęcia zespołu archiwalnego"157, a naukowe pojęcie zespołu archiwalnego jest warunkiem koniecznym istnienia archiwistyki jako nauki.

Konarski kontynuuje swój wywód na temat archiwistyki. Jak wygląda ona jego oczami? „Archiwistyka jest nauką stosowaną, ma cele praktyczne. Ma ona dawać badaczowi możliwość dotarcia do materiału aktowego

155 Tamże, s. 25.

156 K. Konarski, Podstawowe zasady archiwistyki, „Archeion” 1951, t. 19-20, s. 19.

157 Tamże, s. 19. 
i orientację w nim"158. Zatem celem archiwistyki jest wypracowanie takich metod porządkowania archiwaliów i ich opisania, by jak najbardziej umożliwić do nich dotarcie badaczowi. Konarski umiejscawia też archiwistykę wśród innych nauk, a jego wykład jest tak przejrzysty, że trudno nie przywołać znów jego słów. Archiwistyka „nie jest techniką, ale nauką; korzysta z osiągnięć innych nauk. Jest nauką pomocniczą historii, zazębioną jak najściślej z innymi takimiż naukami, jak paleografia, genealogia i sfragistyka, ale wykracza daleko poza ich obręb i obejmuje szerokie dziedziny nauk humanistycznych z nauką prawa w pierwszym rzędzie. Archiwiście, obracającemu się nieustannie w sferze zagadnień ustrojowych, znajomość prawa ułatwia niezmiernie orientację w gąszczu akt. Innym takim drogowskazem, specjalnie doniosłym w dzisiejszej dobie, będzie znajomość zagadnień gospodarczo-społecznych, a więc ekonomii. Nie obce wreszcie archiwiście są nauki przyrodnicze. Zagadnienie konserwacji akt opiera się już dziś nie na przestarzałych empirycznych metodach, ale na laboratoryjnych mikrobiologicznych i chemicznych studiach i zabiegach"159. Rozszerza tym niezmiernie obszar zainteresowania samej archiwistyki. Można powiedzieć, że zagadnienia prawne, zwłaszcza prawno-ustrojowe współistniały od zawsze z archiwalnymi. Umieszczenie nauk przyrodniczych i zagadnienia konserwacji jest niewątpliwie wynikiem zainteresowań Konarskiego. Symptomatyczne jest jednak to, że obok młodej archiwistyki nie postawił on równie młodej informacji naukowej, z której archiwistyka tyle w późniejszym okresie czerpa$\mathrm{ła}^{160}$. Archiwistyka pozostaje w jego mniemaniu nauką pomocniczą historii, a wiele zagadnień czerpie z prawa.

Przechodzi do właściwej części pracy, którą dzieli na trzy ustępy, mianowicie zagadnienie aktu, zagadnienie zespołu akt, oraz zagadnienie archiwum. Elementy te zostaną bliżej zanalizowane w dalszej części pracy, tutaj należy jednak zaznaczyć, iż wybranie takich właśnie części, i taki ich układ oznacza większe przemyślenie przedmiotu archiwistyki. Pozostaje nim bezsprzecznie zespół. Zagadnienie aktu omawia to jak zespół powstaje, skąd się bierze. Zagadnienie zespołu świadczy o samym zespole, jego rekonstrukcji i inwentaryzacji, tym samym porządkowanie i inwentaryzacja pozostają w centrum zagadnień metodycznych archiwistyki.

\footnotetext{
158 Tamże, s. 20.

159 Tamże.

160 K. Leśniewska, dz. cyt., s. 43-45.
} 
Centralnemu miejscu zespołu i kluczowej roli czynności związanych z jego rekonstrukcją i inwentaryzacją daje wyraz, przechodząc do omówienia zagadnienia archiwum. „Od pojęcia zespołu, dookoła którego grupują się wszystkie czynności archiwalne: rekonstrukcja, klasyfikacja i inwentaryzacja, przejdźmy z kolei do nadrzędnego pojęcia, jakim w stosunku do zespołu będzie archiwum"161. Wymienia zasadnicze cechy archiwum, które jest miejscem przechowywania archiwaliów, urzędem wiary publicznej oraz placówką naukową i wynikające $\mathrm{z}$ tych cech funkcje archiwów. Tak przedstawiony zakres archiwistyki, opisany przez funkcje archiwów jest bardziej przejrzysty niż chociażby poprzednio zaproponowany w konspekcie pracy Archiwistyka polska. I tak jako „skład archiwaliów” archiwum gromadzi, przechowuje i zabezpiecza akta (funkcje te potraktowane łącznie), porządkuje zgromadzony zasób i inwentaryzuje go zgodnie z wymaganiami archiwistyki, udostępnia archiwalia oraz odstępuje akta, przez co ma na myśli ekstradycję, przenosiny w związku w organizacją sieci archiwalnej oraz brakowanie akt (na makulaturę). Jako urząd wiary publicznej archiwum wydaje odpisy i opracowuje „wywody archiwalne”, natomiast do zadań naukowych archiwum Konarski zalicza organizację własnego życia naukowego, organizację zebrań naukowych, opracowanie normatywów wewnętrznych, wykonywanie kwerend do celów naukowych, organizowanie i wykonywanie prac rekonstrukcyjnych i inwentaryzacyjnych o szerszym zakresie, organizowanie wystaw i pokazów, podejmowanie akcji wydawniczych w zakresie źródeł i pomocy archiwalnych ${ }^{162}$. I chociaż szeroko opisuje funkcję naukową, za kluczową czynność uznaje jednak wydawanie źródeł, stwierdzając, że „na pełnej wysokości zadania stanie archiwum dopiero wtedy, kiedy nakreśli, zorganizuje i wykona w możliwie szerokim zakresie i w możliwie niedługim czasie program wydawniczy źródeł zawartych w jego zespołach" ${ }^{163}$. Nie można wykluczyć, że na takie ważne miejsce oddane tej czynności wpływ miały zniszczenia wojenne, o czym pisał wcześniej.

Da się zauważyć, iż w stosunku do wcześniejszych prac Konarski w Podstawowych zasadach archiwistyki przeniósł nieco punkt ciężkości co do przedmiotu archiwistyki z zespołu archiwalnego na zagadnienie aktu i jego badanie. Myśl ta widocznie dojrzewała w nim, aż ostatecznie uznał analizę aktu za

\footnotetext{
161 Tamże, s. 98.

162 Tamże, s. 98-99.

163 Tamże, s. 104.
} 
podstawę archiwistyki. W swym niepublikowanym artykule przygotowanym na Kongres Nauki Polskiej stwierdził, że rola aktu w życiu człowieka jest tak ważna, iż nawet nie trzeba jej uzasadniać. Jak zatem ma się archiwistyka do zagadnienia aktu? Jak pisze Konarski: „zdawałoby się, że archiwistyka, a więc nauka poświęcona w całości owym aktowym emanacjom stosunków ludzkich, powinna w pierwszym rzędzie zając się ich analizą, ustalić ich zakres, sformułować ich definicję, dać charakterystykę prawną, słowem uzasadnić i stwierdzić olbrzymią doniosłość życiową aktu czy dokumentu" ${ }^{164}$.

Rozszerza też zakres zainteresowania archiwistyki nie tylko na akta i dokumenty, ale w związku z pojawieniem się pojęcia dokumentacji, „które ogarnia wszystkie wieki od skorupki aż po mikrofilm i wszystkie typy źródeł od dokumentu pergaminowego do dowolnego przedmiotu, jeśli przypadnie mu w udziale rola dowodu prawnego", właśnie na te źródła ${ }^{165}$.

Tak widziana archiwistyka ma się stać zatem przede wszystkim nauką o akcie. Umiejscawia ją zatem wśród innych nauk, przede wszystkim określa jej stosunek do dyplomatyki. „Nie uchybiając niczym dyplomatyce, oceniając w pełni jej dorobek w zakresie poznania dziejów i znaczenia dokumentu, nie można nie stwierdzić, że nauka o akcie obejmuje horyzont nieporównanie rozleglejszy od dyplomatyki i to zarówno pod względem zakresu jak i sposobu ujęcia. Zakresu, bo dyplomatyka obejmuje tylko dokument średniowieczny sensu stricto; sposobu ujęcia, bo omawia głównie jego stronę formalną. Nauka o akcie ogarnia wszelkie wczorajsze czy dzisiejsze formy pisma z wyjątkiem pism pozbawionych adresata (oczywiście w merytorycznym, a nie formalnym znaczeniu tego terminu), pisanych sobie a muzom, ujmuje je zaś nie tylko pod kątem widzenia formalnym, ale i treści, a przynajmniej roli aktu w życiu zbiorowym człowieka" ${ }^{166}$. Nie waha się jednocześnie stwierdzić, że dyplomatyka jest częścią nauki o akcie, przy założeniu, że dokument jest jedną z form aktu $^{167}$. Koniecznością jest jednak ustalenie i jasne określenie wzajemnego stosunku pojęć dokumentu i aktu.

Prowadzi go to do stwierdzenia, że „Zespołowość czy zbiorowość aktu jest kamieniem węgielnym całej archiwistyki. Stąd wniosek prosty - bez nauki o akcie nie można mówić o pełnym wszechstronnym rozwoju archiwisty-

164 K. Konarski, „Analiza aktu jako podstawa archiwistyki”, APAN, Materiały Kazimierza Konarskiego, sygn. 2, s. 1.

165 Tamże.

166 Tamże.

167 Tamże. 
ki"168. Widać zatem, że w określeniu przedmiotu archiwistyki idzie on coraz głębiej. Początkowo kamieniem węgielnym archiwistyki była zasada proweniencji, później rolę tę odgrywało wykrystalizowanie się pojęcia zespołu archiwalnego, teraz rolę te spełnić ma część składowa tegoż zespołu czyli akt. Zakres tej nauki obejmować ma badania terminologiczne, zwłaszcza ustalenie definicji aktu i dokumentu, konieczne jest także opracowanie systematyki aktu, analityki aktu (ustalenie części składowych aktu), genetykę aktu (powstawanie aktu w kancelarii) oraz opracowanie analizy prawnej aktu ${ }^{169}$. Kluczową jednak rolę ma tu terminologia, jak stwierdza Konarski, należy „zacząć od ustalenia terminologii aktu, a w ogóle od ustalenia terminologii archiwalnej"170.

Bez wątpienia na takie widzenie archiwistyki przez Konarskiego miała wpływ lektura Aktenkunde Heinricha Ottona Meisnera ${ }^{171}$, należy jednak podkreślić, że myśl ta w nim dojrzewała już wcześniej, gdyż zagadnienie aktu zawsze odgrywało w jego pracach dużą rolę ${ }^{172}$.

Brak już w późniejszej twórczości Konarskiego jakiegoś szerokiego ujęcia archiwistyki. Ciekawie jednak prezentują się jego poglądy na archiwistykę prezentowane przy okazji niektórych publikacji, m.in. recenzji, w których powraca do omawianych wcześniej już wątków. I tak na przykład przy recenzji tłumaczenia na język polski rosyjskiego podręcznika Teoria i praktyka pracy archiwalnej powraca do problemu lokalnego charakteru archiwistyki jako nauki. Zauważa, że „archiwistyka jest nauką tak silnie zrośniętą ze swym lokalnym podłożem, że przeniesiona na inny grunt, jeśli w ogóle nie ulegnie zniekształceniu, traci znaczną część swych wartości naukowych, które nie są w stanie puścić korzeni w obcej dla nich glebie. Archiwistyka to nie matematyka z jej uniwersalnymi nie zmieniającymi się pod żadną długością czy szerokością geograficzną tezami, z jej niebywale ścisłym i uniwersalnym

168 Tamże, s. 5.

169 Tamże.

170 Tamże, s. 6.

171 H. O. Meisner, Aktenkunde. Ein Handbuch für Archivbenutzer mit besonderer Berücksichtigung Brandenburg-Preußens, Berlin 1935; tenże, Urkunde Und Aktenlehre der Neuzeit, Leipzig 1950.

${ }^{172}$ K. Konarski, Dalekie a bliskie, s. 332; tenże, „Analiza aktu”, s. 2; por. Z. Chmielewski, Od archiwistyki „,bez zasad” do archiwistyki „,bez granic” - czyli archiwistyka europejska od Casanovy do Papritza, „Archiwista Polski” 2007, nr 2, s. 63. 
językiem"173. Zajmuje się jednak nie tylko archiwistyką w ogóle, ale też jej zakresem czyli funkcjami i ich hierarchią. Wręcz za ujemną cechę konstrukcyjną podręcznika uważa nierównomierne rozłożenie materiału, które polegać ma na, jego zdaniem, zbyt dużym poświęceniu uwagi „ważnemu, ale nie najważniejszemu zagadnieniu metodycznemu, jakim w archiwistyce jest brakowanie akt”. Za to zdecydowanie zbyt mało uwagi poświęcono zagadnieniu, według niego najważniejszemu, jakim jest klasyfikacja i systematyzacja archiwaliów ${ }^{174}$.

Miejsce archiwistyki wśród innych nauk omawia przy okazji recenzji książki Meisnera Urkunde und Aktenlehre der Neuzeit. Nadal uznaje archiwistykę za naukę pomocniczą historii, ale widzi jej odrębność w stosunku do innych nauk pomocniczych. „Najważniejszą usterką konstrukcyjną jest symbioza dwóch gałęzi nauk pomocniczych w jednej niewielkiej książce. Archiwistyka, która sama w bardzo ścisłym treściwym ujęciu wypełniłaby wydawnictwo obszerniejsze od całej książki Meisnera, została tu wtłoczona w postaci rozdziału między dwa inne, o pokrewnej, ale tylko pokrewnej treści”. Paradoksalne jest według niego bardzo szczegółowe potraktowanie zagadnień dyplomatycznych i aktoznawczych, kosztem „najważniejszych problemów archiwalnych, jak zagadnienie dziedziczenia akt, ich scalenia, konserwacji, brakowania itd." 175 . Stwierdzeniem tym zupełnie odcina się od swoich założeń co do archiwistyki jako właściwie nauki o akcie.

Jaka jest zatem archiwistyka Kazimierza Konarskiego? Jest bez wątpienia nauką, nie jest wyłącznie zbiorem wiadomości i umiejętności, ale nauką mającą swój przedmiot zainteresowań, zakres, stawiającą sobie cele badawcze. Zagadnienia z zakresu archiwistyki dzieli Konarski na teoretyczne i praktyczne. Do teoretycznych zalicza przede wszystkim problem terminologii. Wielokrotnie podkreśla wagę badań terminologicznych i konieczność ujednolicenia jej, gdyż bez terminologii archiwistyka jako nauka nie może funkcjonować. Do teorii zalicza również badania archiwoznawcze. Jest jednak archiwistyka przede wszystkim nauką stosowaną, dlatego za zasadne uznaje czynienie odstępstw od teorii na rzecz praktyki. To właśnie praktyka określa zakres ba-

173 K. Konarski, rec. K. G. Mitjaev, Teoria i praktyka pracy archiwalnej, tłum. W. Suchodolski, K. Murza-Murzicz, A. Rybraski, A. Sienkiewicz, Warszawa 1954, „Studia Źródłoznawcze” 1957, t. 1, s. 253.

174 Tamże, s. 254.

175 K. Konarski, rec. H. O. Meisner, Urkunde Und Aktenlehre der Neuzeit, Leipzig 1950, „Studia Źródłoznawcze” 1958, t. 2, s. 168. 
dań archiwalnych przez czynności, jakie wykonują archiwach, ich funkcje. Początkowo Konarski jedynie je wymienia, daje pewien zakres czynności wykonywanych przez archiwistów, czynności, z którymi sam spotkał się w swej praktyce archiwalnej. Dojrzały wyraz i systematyzację tychże funkcji daje dopiero w Podstawowych zasadach archiwistyki, kiedy porządkuje je według, jak to określa, cech archiwum, czyli składu archiwaliów, instytucji wiary publicznej i placówki naukowej. Określony tymi funkcjami zakres obejmuje gromadzenie, przechowywanie i zabezpieczanie archiwaliów, ich porządkowanie i inwentaryzację, udostępnianie oraz odstępowanie, a także wystawy i pokazy oraz opracowanie normatywów wewnętrznych. Wymienione ponadto przez Konarskiego zadania, jak wydawanie odpisów, przeprowadzanie kwerend czy organizacja zebrań naukowych, należy zaliczyć już do czynności czysto praktycznych. Różne funkcje w różnym okresie zyskują na znaczeniu. Do ważnych zalicza m.in. zakwalifikowane do działalności naukowej wydawanie źródeł ${ }^{176}$, jednak to porządkowanie i inwentaryzacja odgrywają wiodącą rolę i są kluczową funkcją archiwów, wyraźnie wysuwając się przed inne.

Wynika to z centralnego umiejscowienia zagadnienia zespołu archiwalnego. To właśnie zespół jest przedmiotem badań archiwistyki, a jej zakresem - to, co archiwiści z nim robią, jednak z kluczowym miejscem zarezerwowanym dla problematyki porządkowania i inwentaryzacji, w myśl zasady, że archiwistyka jest nauką stosowaną, mającą jak najbardziej umożliwić badaczowi dotarcie do pożądanych materiałów i orientację w nich. Duże znaczenie w koncepcji Kazimierza Konarskiego miało od początku zagadnienie aktu, do tego stopnia, iż w pewnym momencie uczynił je przedmiotem zainteresowań archiwistyki, jednak myśl ta rzucona raz, nie powróciła już w orbitę jego zainteresowań i nie wyparła nigdy zespołu jako głównego przedmiotu archiwistyki. Widzenie przedmiotu wzbogacał, ale zasadniczo go nie zmieniał.

W kontekście ważnej roli, jaką w archiwistyce odgrywa problem porządkowania i inwentaryzacji, najlepiej ujawnia się wizja Konarskiego, przejęta od Eugenio Casanovy o archiwistyce bez zasad. Niezachwiane są zasadnicze dogmaty archiwistyki co do pojęcia zespołu archiwalnego, czy zasady proweniencji, jednak właśnie przez tę kategoryczną zasadę proweniencji pokazuje, iż nie można w archiwistyce wysnuć jakiś ogólnych twierdzeń, stanowczych

176 Jest to znak czasów powojennych, gdy archiwiści dojrzeli do myśli uchronienia tego, co przetrwało wojenną pożogę. 
założeń. Wszystkie działania muszą dyktować same akta, a właściwie życie, którego są odzwierciedleniem.

Konarski podkreślał też wielokrotnie, iż archiwistyka nie jest nauką uniwersalną. Musi ona posiadać swój lokalny charakter, kształtować się musi na podstawie rodzimych przykładów z praktyki archiwalnej, inaczej nie ma racji bytu.

Warto jeszcze odnaleźć w myśli Konarskiego miejsce archiwistyki wśród innych nauk. Wyraźnie należy podkreślić, że archiwistyka Kazimierza Konarskiego jest nauką pomocniczą historii. Korzysta ona także z osiągnięć innych nauk pomocniczych, jak np. paleografia. Nie do końca potrafił jednak Konarski ustalić stosunek archiwistyki do dyplomatyki. Początkowo uważał, że zagadnienia dyplomatyczne należy włączyć w zakres badań archiwalnych, by następnie wysunąć tezę, że archiwistyka jest czymś ponad dyplomatyką i dyplomatyka jest jedynie jej częścią składową. Archiwistyka czerpie ponadto nie tylko z nauk historycznych, ale także z prawa, ekonomii czy nawet nauk przyrodniczych. Ostatecznie jednak stwierdził, że archiwistyka ma własne cele i zakres badawczy i to na nich skupiać się muszą archiwiści, by dążyć do ostatecznego ustalenia podstaw archiwistyki i jej dalszego rozwoju. Jednak archiwista pozostaje historykiem, a archiwistyka nawet samodzielna stoi ramię $\mathrm{w}$ ramię z historią, bez niej nie mając racji bytu.

\section{ZASADA PROWENIENCJI I ZESPÓł ARCHIWALNY JAKO WEAŚCIWY PRZEDMIOT ARCHIWISTYKI}

Wcześniej pokazałam, jak ważne miejsce w swych rozmyślaniach przeznaczył Konarski na zasadę proweniencji. Jest ona „podsumowaniem, syntezą i kamieniem węgielnym całej archiwistyki”. Pozostałe zagadnienia są według Konarskiego jedynie jej rozwinięciem i konsekwencją i tak też w swoich rozmyślaniach je traktuje. Aby jednak móc mówić o zasadzie proweniencji, należy dogłębnie przyjrzeć się jej istocie, czyli zagadnieniu zespołu archiwalnego. Wydaje się to zrozumiałe, gdyż Konarski uznaje zespół archiwalny za coś naturalnego, podświadomego, natomiast zasada proweniencji jest jedynie naukową odpowiedzią, wzięciem w pewne ramy teoretyczne zagadnienia zespołu ${ }^{177}$.

177 Tenże, Z zagadnień, s. 108. 
Jak Konarski wyjaśnia pojęcie zespołu? Wychodzi od momentu tworzenia się zespołu. Zauważa, że akta pochodzące z jednej registratury są ze sobą jak najściślej związane, a wynika to z faktu, że są wytworem jednego urzędu i w trakcie powstawania (załatwiania sprawy) krzyżują się, a w pewnym momencie tworzy się z nich zamknięta, zwarta, organiczna całość - zespół archiwalny ${ }^{178}$.

W kontekście zespołu, jako jego przeciwieństwo, omawia zbiór, który nazywa zasobem. Jest to zbiór archiwaliów niepowiązanych kancelaryjnie, łączonych charakterem, treścią bądź sposobem powstawania, materiały te nie posiadają żadnej jednak więzi wewnętrznej, można je dowolnie zwężać i rozszerzać, segregować jak w bibliotece, wg rozmaitych systemów ${ }^{179}$. Już więc w tym momencie widać znaczenie kancelaryjnego pochodzenia w zagadnieniu zespołu, właśnie przez podkreślenie, że zasób tego kancelaryjnego pochodzenia nie ma, nie ma zatem koniecznej w zespole wewnętrznej więzi.

Przez owo kancelaryjne pochodzenie zespołu nie można powiększyć, jest całością zbudowaną wg logicznego planu, którego naruszenie zniweczyłoby od razu całą organizację i spoistość wewnętrzną. Struktura zespołu może ulec naruszeniu, zespół może zostać zdekompletowany, rozproszony, ale kiedy zostanie odbudowany, staje się całością zamkniętą. Zespół zatem jest to „jednostka archiwalna, stanowiąca organiczną całość i składająca się z całokształtu registratury danego urzędu"180.

Dla ukazania istoty zespołu Konarski daje szerokie ujęcie zespołu archiwalnego w dwóch aspektach - prawno-administracyjnym (zespół jako wytwór oficjalnej działalności urzędu) oraz archiwalnym (zespół jako obiekt archiwalny). Wydaje się to logiczne i zrozumiałe, gdyż obrazuje niejako etapy „życia” zespołu. Po powstaniu w urzędzie (charakterystyka pierwsza), opisuje archiwalny etap zespołu. Jednak zagadnienia, jakie porusza w poszczególnych punktach, nie wydają się do końca przemyślane.

W charakterystyce prawno-administracyjnej wychodzi od założenia: „zespół archiwalny jest wytworem oficjalnej działalności urzędu na przestrzeni pewnego zamkniętego okresu czasu i na pewnym określonym terytorium" ${ }^{181}$. Jest to bardzo ważne, bo ustawia cały jego dalszy wywód. Żaden zespół, zda-

\footnotetext{
178 Tamże.

179 Tamże.

180 Tamże, s. 109.

181 Tamże.
} 
niem Konarskiego, nie może obejmować kilku wieków, bo żaden urząd nie trwa przez taki długi okres ${ }^{182}$. Ścisły związek akt z urzędem zauważalny jest także przez fakt występowania w zespole wszelkich przeobrażeń, jakim uległ urząd. W taki sposób uzasadnia zajęcie się w opisie prawno-administracyjnym zespołu zagadnieniami sukcesji ${ }^{183}$. Przy okazji problemu sukcesji wprowadza pojęcie zasady niepodzielności zespołu archiwalnego jako kluczowej w działalności archiwalnej. Tematykę sukcesji rozszerza na zagadnienia międzynarodowe, widząc daleko idące jej konsekwencje, jak burzenie porządku archiwalnego na danym terytorium, zauważając, że akta wywiezione poza miejsce ich powstania tracą rację bytu, skąd wynika bardzo ważny czynnik organizacji życia archiwalnego, którym jest związek archiwaliów z terytorium, na którym powstały i którego dotyczą ${ }^{184}$. Zauważa jednak negatywny związek akt z terytorium, gdyż jak pisze, „nowe terytoria administracyjne ciągną ku sobie archiwalia z siłą, która może się okazać dostatecznie skuteczną dla rozbicia dawnego archiwalnego zespołu"185, jego wewnętrznej więzi, która jest tak istotna. Rozważania, dla których przesłankami były: związek kancelaryjny między aktami, związek organiczny akt z urzędem, z którego zespół pochodzi oraz związek geograficzny z terytorium, z jakiego akta pochodzą, doprowadził Konarskiego do wniosku tożsamego z przesłankami. „Z całej powyższej charakterystyki zespołu, jako wytworu działalności oficjalnej urzędu, wysuwają się, jak widzimy, na czoło trzy najważniejsze cechy zespołu. Związek kancelaryjny między poszczególnymi częściami zespołu. Związek organiczny z urzędem, z jakiego zespół pochodzi. Związek geograficzny z terytorium, jakiego urząd dotyczy"186. Dowodem natomiast na te twierdzenia były przykłady ze znanej Konarskiemu praktyki archiwalnej, potwierdzające założenie, że archiwistyka musi posiadać swój lokalny charakter.

Wyprowadzenie jednak tych cech istotne jest w celu pokazania fundamentalności zasady proweniencji. Zauważa, że cechy te mogą być sprzeczne w stosunku do siebie i tu widzi doniosłą rolę tejże zasady jako ich spoiwa ${ }^{187}$.

182 Widać tu spojrzenie na zespoły w perspektywie urzędu istniejących w XIX w., podczas gdy urzędy dawniejsze istniały przez kilka wieków.

183 Tamże, s. 110.

184 Tamże, s. 117.

185 Tamże, s. 118.

186 Tamże.

187 Tamże, s. 119. 
Porusza też kwestię nazewnictwa tej zasady, idąc za Józefem Paczkowskim i ustalając dla niej nazwę zasada przynależności kancelaryjnej ${ }^{188}$.

Tak dokładne ukazanie problematyki ustrojowo-administracyjnej zespołu i w kontekście tego ważności zasady proweniencji pozwala Konarskiemu przejść do omówienia drugiej natury zespołu w kategoriach obiektu archiwalnego. W tym rozumieniu chodzi o ustrój kancelarii, o wewnętrzny ustrój registratury, chociaż wydawałoby się, że widzenie zespołu jako obiektu archiwalnego winno dotyczyć tylko tego, co archiwiści robią z zespołem. Natomiast według niego „są to [...] raczej dzieje formalnego urzędowania, dzieje kancelarii urzędu, a nie samego urzędu, jako całości” ${ }^{189}$. Badania kancelarii są konieczne dla historyka dla zrozumienia merytorycznego ustroju urzędu, a dla archiwisty dla zorientowania się w spuściźnie akt.

Registraturalne rozumienie zespołu potwierdził Konarski podczas opisu archiwaliów łódzkich w $\mathrm{AAD}^{190}$. Mówił tam o zespole w ramach akt jednego urzędu, czyli zespole Rady Głównej Opiekuńczej w Aktach Komisji Spraw Wewnętrznych. Dalej jednak pisał o archiwum Komisji Spraw Wewnętrznych, w skład którego wchodziło kilka zespołów powstałych z registratur działających przy Komisji ${ }^{191}$. Dlatego też dzisiejsze rozumienie (i nawet późniejsze rozumienie Konarskiego) zespołu jako całości akt urzędu odpowiadało ówczesnemu jego postrzeganiu archiwum urzędu. Wówczas jednak powszechnie uważano, że po urzędzie może zostać kilka zespołów, kiedy było kilka oddzielnych registratur ${ }^{192}$.

Sprzeciwiał się jednak Konarski kategorycznie nazywaniu zespołu archiwalnego terminem archiwum, który w Polsce propagował Józef Siemieński, natomiast we Włoszech Pio Piacchiai. Konarski krytykował takie poczynania jako wprowadzające zamieszanie terminologiczne ${ }^{193}$. W recenzji książki, jako podkreślenie słuszności swojego dążenia do rozróżnienia terminów archiwum i zespół archiwalny, zauważa, że autor podaje schemat podziału ar-

188 Na temat zasady i kształtowania się jej nazwy por. W. Chorążyczewski, Zasada proweniencji w polskiej myśli archiwalnej do roku 1939, [w:] Torunskie konfrontacje archiwalne, s. 105-110; Z. Chmielewski, Polska myśl archiwalna, s. 87.

189 K. Konarski, Z zagadnień, s. 120.

190 Tenże, Archiwalia tódzkie w Archiwum Akta Dawnych w Warszawie, „Rocznik Łódzki” 1928, t. 1, s. 98.

191 Tamże.

192 W. Chorążyczewski, Zasada proweniencji, s. 119.

193 Tamże, s. 116-118, B. Ryszewski, O niektórych podstawowych, s. 105. 
chiwów na sekcje, sekcje na tytuły, tytułów na klasy, klas na podklasy, ale nie precyzuje, do którego „archiwum” to się odnosi ${ }^{194}$. Nie zauważył jednak, że Włoch niejako wyróżnia poziomy struktury zasobu archiwalnego, czego Konarski w takim pogłębionym ujęciu nie dostrzegał. Sam przy opisie wspomnianych archiwaliów łódzkich mówił wyłącznie o większych grupach archiwaliów lub pojedynczych fascykułach, nie nazywając ich jakoś szczególnie ${ }^{195}$.

Samo jednak rozumienie zespołu przez Konarskiego i Picchiaiego jest dość zbieżne. Jak pisze Konarski: „pojęcie zespołu archiwalnego, choć niesformułowane nigdzie wyraźnie, znajduje swą charakterystykę pośrednią w rozdziale, poświęconym organizacji archiwum. Widzimy tam tendencję do oparcia organizacji tej na dawnych podstawach zespołu, kiedy był on jeszcze żywą formacją, uwzględnienie indywidualizmu każdego zespołu, który wymaga przystosowania się archiwisty do odrębnych właściwości jego budowy, widzimy uznanie niepodzielności zespołu i konieczność rekonstrukcji jego rozproszonych części”196.

W swoim podręczniku Konarski rozszerzył opis zespołu w stosunku do artykułu z 1927 r. Zauważa, że na zamknięcie zespołów archiwalnych mają wpływ nie tyle wypadki dziejowe, co reformy administracyjne. Daje także szerszy wyraz swojemu rozumieniu urzędowego pochodzenia zespołu. Podkreśla, że mówiąc „urząd”, nie ma na myśli wyłącznie instytucji państwowych, ale także samorządowe i inne. Jednak stawia warunek, że muszą mieć one ,jednolity system administracyjny”, czyli pewną organizację, kompetencje, które odbiją akta - zespół ${ }^{197}$. Zatem warunkiem koniecznym powstania zespołu jest jego urzędowe, a co za tym idzie kancelaryjne pochodzenie.

Powtarza on dokładnie swoje ustalenia co do urzędowego pochodzenia zespołu i istoty zasady proweniencji, wprowadza jednak zapowiedziany opis zespołu jako obiektu archiwalnego. Zaznacza, że zespół pozostaje niepodzielną pozostałością registratury, jednak wypadki mogą spowodować, że nie trafi on w całości do archiwum, dlatego uważa, że kryterium całości można złagodzić przez stwierdzenie, że zespół to grupa akt, który jest jedyną pozostałością po registraturze (co do którego istnieje takie przeświadczenie, nie ma wiadomości, jakoby jakieś części zespołu były poza nim). Dodaje, że jeśli po-

${ }^{194}$ K. Konarski, $Z$ archiwistyki obcej, rec. podręcznika Pio Pecchiai, Manuale prawico per gliarchivisti, Milano 1928, „A Archeion” 1928, t. 4, s. 132.

195 Tenże, Archiwalia tódzkie, s. 78.

196 Tenże, $Z$ archiwistyki obcej, s. 132.

197 Tenże, Nowożytna archiwistyka, s. 17. 
zostałość po registraturze znajduje się w dwóch archiwach, nie można mówić o zespole ${ }^{198}$. Nie napisał jednak, czym taki fragment jest.

Wprowadzeniem do zagadnienia rekonstrukcji archiwalnej jest stwierdzenie, że każdy zespół ma swoją odrębną budowę, wręcz - jak pisze Konarski - osobowość, co archiwista musi uszanować przy rekonstrukcji i do każdego podchodzić indywidualnie. Musi jednak poznać części składowe, co prowadzi go do omówienia części składowych zespołu archiwalnego, czyli dokumentu i aktu, których daje charakterystykę $e^{199}$.

Mimo zachwiania w pewnym momencie znaczenia zasady proweniencji, pozostała ona w rozważaniach Konarskiego naczelną zasadą archiwistyki, wykrystalizowaną w toku badań archiwalnych, jednak będącą podświadomą i odwieczną ${ }^{200}$. Razem z krystalizowaniem się pojęcia zasady proweniencji, kształtowało się pojęcie zespołu archiwalnego, w ten sposób powstał termin, którego definicja obejmowała „zamknięty całokształt archiwalny o budowie neutralnej, obiektywnej, niezależnej od indywidualizmu tego czy innego archiwisty, wyrosłej na gruncie praw ciążenia archiwalnego"201.

Wyklarowanie się pojęcia zespołu archiwalnego pozwoliło Konarskiemu pogłębić dociekania na ten temat w kierunku rozszerzenia klasyfikacji zespołów. Problematyce rozróżnienia pojęć zespołu, zespołu złożonego i grup zespołów poświęcone było zebranie naukowe AGAD 1 grudnia 1950 r., na którym Andrzej Sienkiewicz wygłosił referat o takim tytule. W dyskusji nad referatem żywo brał udział Konarski. Najpierw wyraził on swoje zdanie na temat grupy zespołów, uważając, że jest to konstrukcja wyjątkowa, zarezerwowana zazwyczaj do zespołów szczątkowych. W innych wypadkach nie należy łączyć zespołów w całości logiczne, niepowiązane kancelaryjnie. W dyskusji Adam Wolff zauważył pierwotne rozumienie terminu „zespół grupowy” oznaczające zespoły powiązane rzeczowo, a nie kancelaryjnie. Była to odpowiedź na twierdzenia autora referatu, który określił zespół złożony jako twór „kilku urzędów, a więc i registratur, mający zakres działania i kompetencje analogiczne nawzajem się przenikające, a) hierarchicznie zależne, b) hierarchicznie równorzędne" 202 , czemu Konarski się sprzeciwił, uznając,

198 Tamże, s. 32-33.

199 Na wartość szerokiego opisania procesu aktotwórczego przez Konarskiego zwrócił uwagę Z. Chmielewski, Polska myśl archiwalna, s. 111.

200 Tenże, Terminologia archiwalna, s. 72.

201 Tamże.

202 AGAD, AZ, sygn. 19/12, s. 85. 
że zespołów takich nie należy stwarzać. Dalej w dyskusji Konarski powtórzył omawiane już wcześniej cechy zespołu dotyczące jego związku z terytorium, obejmowania przez zespół całości dokumentacji urzędu, zarówno przez niego wytworzonej, jak i zgromadzonej. Trudno stwierdzić, czy spostrzeżenie mówiące o tym, że zespół tworzą akta wytworzone i zgromadzone przez urząd, z którego przecież wyniknęła zmiana nazwy zasady proweniencji na zasadę przynależności kancelaryjnej, nie było oczywiste i ówcześnie powszechnie zrozumiałe, czy po prostu Konarski uważał to za godne zaznaczenia.

Zebranie to przyniosło jednak dalsze owoce w zakresie teorii zespołu archiwalnego. Zespół archiwalny jest zdaniem Konarskiego zespołem, nawet jeżeli w archiwum znajduje się tylko jego część początkowa i co pewien czas dopływają do niego nowe partie materiałów. Jest wtedy zespołem otwartym. Nie jest natomiast zespołem zamkniętym do momentu, kiedy istnieje urząd, z którego akta tego zespołu pochodzą ${ }^{203}$.

Dokonuje także rozróżnienia genezy powstawania zespołu złożonego. „Mogą występować cztery różne przyczyny: a) dziedziczenie akt przez urząd sukcesyjny, b) przekazywanie współczesne akt z jednego urzędu istniejącego do drugiego w związku ze zmianą kompetencji urzędów, c) istnienie urzędu o kilku kancelariach organizacyjnie związanych odgórnie, d) obarczenie zespołu masą załączników np. Prokuratoria Generalna"204. Takie rozróżnienie zespołu złożonego nie daje jednak jasnej odpowiedzi, czym on jest. Można odnieść wrażenie, że mianem zespołu złożonego określa Konarski wszystkie te twory zespołowe, które nie są „proste”. Zarysowuje się tendencja, żeby za zespół złożony uważać każdy o skomplikowanej strukturze wewnętrznej. Przy tej okazji daje jednak Konarski pewne wyjaśnienie na temat opisywanych przez siebie akt Zarządu Pałaców Cesarskich, stwierdzając, że „o tym, czy jest to zespół złożony czy grupa zespołów, decyduje fakt, czy nastąpiła żywa sukcesja między zespołami czy też nie" ${ }^{205}$.

Przybliża także problematykę wprowadzonych już wcześniej zespołów szczątkowych i variów w archiwum. Najliczniejszą grupę wśród variów stanowią materiały pokrewne zespołom, dlatego trudno ją rozwiązać; podkreśla jednak, że „wcielić ich do zespołu nie pozwala zasada przynależności zespo-

\footnotetext{
203 Tamże, s. 86.

204 Tamże.

205 Tamże, s. 87.
} 
łowej"206. Co do zespołów szczątkowych zawsze praktyczny Konarski proponuje wprowadzenie ograniczenia, uważając, że za takie zespoły powinny obejmować nie więcej niż 20 jednostek. Rozumienie takie zostało skrytykowane przez Kazimierza Arłamowskiego ${ }^{207}$. Natomiast „sprawa wydzielenia szczątków w osobny zbiór, czy pozostawienia ich na miejscu wyznaczonym topograficznie między zespołami, jest rzeczą drugorzędną, głównym celem jest zapewnienie szczątkom stanowiska zespołów”. Stoi zatem na stanowisku, żeby nawet $\mathrm{z}$ najmniejszych szczątków tworzyć zespoły, aby miały osobne miejsce w ewidencji i opisie archiwum ${ }^{208}$.

Podsumowanie i najpełniejszą formę opisu zespołu i zasady proweniencji dał Konarski, podobnie jak w przypadku omawiania samej archiwistyki, w Podstawowych zasadach archiwistyki. Nie wychodził on już od z góry powziętych założeń, lecz opisał po prostu naturalny proces powstawania i tworzenia zespołu archiwalnego. Konieczne było tutaj wyjście od omówienia zagadnienia aktu, któremu poświęca cały, można rzec, rozdział. Opisanie zagadnienia aktu, czyli pisma w swej urzędowej postaci, jako najmniejszej jednostki archiwalnej, przygotowuje do prac rekonstrukcyjnych, przybliża zagadnienia kancelaryjnych powiązań, które archiwista musi poznać, przystępując do rekonstrukcji. Opis jest bardziej uporządkowany, przedstawia pismo na każdym etapie jego drogi w urzędzie ${ }^{209}$. Wszystkie dalsze elementy, jakie omawia, jak sposoby układu akt w registraturze, formy występujących akt, elementy rozpoznawcze, mają wspomagać proces rekonstrukcji $\mathrm{w}$ archiwum ${ }^{210}$.

Zauważa, że pisma niejako odbijają się. Oznacza to, że to, co pozostało jako minuta w jednym urzędzie, w postaci oryginału jest w innym. Mówi to w kontekście tworzenia akt zastępczych, jednak negatywnie ocenia takie postępowanie, stwierdzając, że „dopiero całokształt akt jakiegoś urzędu daje właściwe wyobrażenie o jego charakterze, roli, kompetencjach, organizacji, słowem o jego życiu, rozwoju i działaniu"211.

Powtarza, że zespół jest wynikiem krzyżujących się nici, które tworzą zwartą, zamkniętą organiczną całość. Jest on podstawą archiwalnej organi-

206 K. Konarski, Szczatki zespotów i varia, s. 93.

207 W. Chorążyczewski, Myśl archiwalna Kazimierza Artamowskiego, „Rocznik Historyczno-Archiwalny” 2012, t. 22.

208 AGAD, AZ, sygn. 19/12, s. 96.

209 Por. K. Konarski, Podstawowe zasady, s. 22-32.

210 Tamże, s. 31-42.

211 Tamże, s. 32. 
zacji, którą określa jako grupę akt, „wytworzonych przez dany urząd, złączonych przeto wspólnym pochodzeniem" ${ }^{212}$. Precyzuje też moment powstawania zespołu archiwalnego. Wcześniej mówił, że zespół to zarchiwizowana registratura, która zamyka się w momencie ustania trwania urzędu, czyli każda reorganizacja, zamknięcie urzędu powodowało niejako zamknięcie registratury i stworzenie zespołu archiwalnego. W takim wypadku dochodziło faktycznie do dziedziczenia zespołów, nie registratur. Teraz zaznacza i precyzuje, że zespół powstaje dopiero wtedy, kiedy akta zostaną przeniesione do archiwum i tam zarchiwizowane. Wymienia też trzy okresy w życiu akt, określając ich użyteczność na każdym etapie. Jest to etap kancelarii, w którym akta są potrzebne do bieżącej działalności; etap składnicy akt, gdzie akta są częściowo użyteczne, oraz etap archiwum, na którym akta do działalności urzędu są już nieużyteczne. Jest to bardzo konsekwentne i przejrzyste prowadzenie wywodu o zespole archiwalnym, gdyż w tym momencie omawia problem zespołu otwartego (urząd istnieje i akta co jakiś czas dopływają) i zamkniętego (urząd kończy działalność i zamyka się w ten sposób zespół) ${ }^{213}$.

Jak zauważyłam wcześniej, Konarski podkreśla przede wszystkim związek zespołu z urzędem, z którego zespół pochodzi ${ }^{214}$. Później dodaje, że zespół ma swoje granice chronologiczne i terytorialne. Nie tworzy jednak z tych założeń jakiś dogmatów, którym podporządkowuje opis zespołu archiwalnego, podaje je po prostu jako jedne z cech opisujących zespół. Kontynuuje jednak myśl urzędowego charakteru zespołu, powtarzając, że „warunkiem uznania za zespół będzie tu nie bardziej lub mniej oficjalny charakter producenta akt, ale posiadanie przez niego kancelarii produkującej akta" ${ }^{215}$. Nadal zatem istnienie kancelarii i kancelaryjne pochodzenie akt jest warunkiem uznania ich po archiwizacji za zespół, będący jednolitą, zwartą i niepodzielną całością.

Konarski wyraźnie zaznacza kluczowe miejsce zespołu archiwalnego, w stosunku do którego zasada proweniencji jest wyrazem więzi, jaka zachodzi między aktami i zespołem a aktami i urzędem. Rezygnuje zupełnie z wcześniejszych założeń, jakoby to zasada proweniencji łagodzić miała sprzeczności wynikające z przyrodzonych cech zespołu, jest ona po prostu odpowiedzią na

212 Tamże, s. 43.

213 Tamże, s. 43-44.

214 Jak zauważa Ryszewski, na temat rozważań Konarskiego, „o jedności i odrębności zespołu archiwalnego decyduje fakt powstania w wyniku działalności jednego urzędu, instytucji lub osoby”. B. Ryszewski, O niektórych podstawowych, s. 107.

215 K. Konarski, Podstawowe zasady, s. 46. 
zagadnienie zespołu. Celowo użyłam określenia „zasada proweniencji”, gdyż w rozważaniach Konarskiego ewoluowało nie tylko samo rozumienie zasady, ale także jej definicja i nazwa. Wcześniej nazwana przez niego zasadą przynależności kancelaryjnej, obecnie zyskała formę zasady przynależności zespołowej definiowanej słowami: „,co w zespole powstało, to w zespole, w tym samym składzie i układzie zachowane i przechowywane być na zawsze powinno" ${ }^{216}$. Na pierwszy rzut oka da się zauważyć pewną nielogiczność w takim definiowaniu zasady proweniencji, kiedy mówi się o tym, co w zespole powstało, z myślą zapewne o urzędowym etapie życia akt, podczas gdy Konarski stwierdza jasno, że o zespole można mówić dopiero w momencie, kiedy trafi on do archiwum. Zrozumiałe jest dążenie autorów tego stwierdzenia do rozszerzenia rozumienia zespołu nie tylko na registraturę, ale na całość akt urzędu. Jednak powoduje to duże zamieszanie. Być może jest to też wynik dążenia Konarskiego do stworzenia lokalnego charakteru archiwistyki, zamiast stawiania na szerokie rozumienie zasady proweniencji i operowania jedynie jego interpretacją.

Bezsprzecznie jednak zaznacza, że „podstawą pracy archiwalnej jest i pozostanie zasada przynależności zespołowej i jej naczelny wyraz - podstawa zespół archiwalny. Zespół nie jest wydedukowaną konstrukcją logiczną, jakimś stworzonym ad hoc aparatem pomocniczym przy porządkowaniu akt, ale naturalnym wytworem zbiorowej pracy ludzkiej, podpatrzonym i uchwyconym przez metody pracy archiwalnej. Jest obiektem, a nie narzędziem tej pracy" ${ }^{217}$. Potwierdza tym samym centralną rolę zespołu archiwalnego w archiwistyce.

W kontekście zespołu porusza on także tematykę zbioru, powtarza jednak swoje wcześniejsze rozważania, zmieniając jedynie terminologię, z zaproponowanego przez niego zasobu, na ogólnie przyjęty termin zbiór. Zauważa jednak istnienie nowego tworu, na pograniczu zespołu i zbioru, jakim są archiwa rodzinne, które zasadniczo mają charakter zbioru, posiadają jednak pewien „rdzeń”, który pozwala je zakwalifikować jako zespół archiwalny. Widać zatem wyraźnie, że znacznemu rozszerzeniu ulega zakres tego, co Konarski nazywa zespołem archiwalnym. Początkowo były to tylko urzędy, następnie także inne instytucje, byleby posiadały kancelarię, teraz także inne całości, które posiadają choć jakieś znamiona kancelaryjnego pochodzenia. Przemy-

216 Tamże, s. 47.

217 Tamże, s. 73. 
ślenia te mogą być jednak wynikiem ówcześnie problemu archiwów, jakim było przejęcie archiwów rodzinnych ${ }^{218}$. Konarski proponuje nawet metodę postępowania z tymi aktami, uważając, że niekoniecznie trzeba traktować jej jako zwarte całości, ale należy wydzielić archiwalia państwowe i włączyć do zespołów, do których należały, jako zespół pozostawić materiały rodzinne, a zgromadzone zbiory włączyć do zbiorów archiwum, np. do zbioru kartograficznego. Widocznie nie był w stanie wznieść się ponad urzędowo-kancelaryjne widzenie zespołu.

Zespół zatem w jego rozważaniach pozostaje spuścizną urzędu, odbiciem samego urzędu i jego organizacji, natomiast każda komórka zespołu odpowiada komórce urzędu w momencie, kiedy on istniał. Wszelkie przeobrażenia urzędu, komplikacje (o czym szerzej dalej) mają wypływ na sam zespół. W myśl tego powtarza, ale częściowo też rozszerza definicję zespołu, uważając, że jest to „historyczny wytwór kancelarii - organiczna całość, na którą składają się zarchiwizowane w całości lub części akta powstałe w wyniku działalności urzędu, instytucji lub osoby" ${ }^{219}$. Z takiej charakterystyki zespołu wyprowadza jego typologię. Omawia zespół prosty (jeśli urząd został zlikwidowany, a wytworzone przez niego akta zarchiwizowane) oraz szeroko omawia problematykę zespołu złożonego. Podaje trzy przypadki takiego zespołu. Jest to zespół obciążony sukcesjami, zespół obciążony załącznikami, wreszcie „trzeci typ zespołu złożonego będziemy mieli w wypadku, gdy urząd o większej skali tworzy nie jedną, ale kilka równoległych autonomicznych kancelarii, a tym samym kilka równoległych zespołów”220. Pokazuje to, mimo że Konarski przystał na pojęcie zasady przynależności zespołowej, przy której powinien uznać, iż jeden urząd tworzy jeden zespół, że autor przyznaje, iż owszem, tworzy jeden zespół, ale jeśli jest kilka kancelarii, to właściwie powstaje kilka zespołów, które składają się na zespół złożony, czyli nadal pozostaje w przeświadczeniu, że zespół jest wytworem kancelarii. Dodatkowo trzeba podkreślić, że zaproponowane przez niego pojęcie zespołu złożonego nie jest klarowne - mianem zespołu złożonego określa wszystko, co nie jest zespołem prostym. Sytuację taką skrytykował Bohdan Ryszewski, uważając, że twierdzenia takie powodują ,powstanie rozbieżności w teorii zespołu złożonego: o ile pierwotnie tworzyć go miały akta różnych, samodzielnych ustro-

$\begin{array}{ll}218 & \text { Tamże, s. } 75 . \\ 219 & \text { Tamże, s. } 70 . \\ 220 & \text { Tamże, s. } 72 .\end{array}$ 
jowo twórców, to teraz według Konarskiego powodem złożoności miały być komplikacje zespołowe widoczne w powikłaniach układu akt, przy czym źródła tych powikłań miały być różnorodne"221.

Dodatkowo wprowadził Konarski pojęcie zespołu grupowego, który stanowić miał „szereg zespołów drobnych lub szczątkowych bądź analogicznego pochodzenia, bądź pokrewnej treści, objętych wspólną ramą inwentarza i innych pomocy archiwalnych"222. Ważne, że nie zaciera się odrębności każdego $\mathrm{z}$ nich. Jest to jednak jedynie konstrukcja archiwalna, mająca na celu ułatwienie orientacji w nich i ich ochronę przed zawieruszeniem. Ten pomysł został zrealizowany w archiwach polskich jako zbiór szczątków zespołów 223 .

W dalszej typologii dzieli zespoły na otwarte i zamknięte, kontynuując swoją wcześniejszą myśl, dokonuje jednak szerszego rozróżnienia zespołów ze względu na stan ich zachowania, na całkowite, fragmentaryczne i szczątkowe, przy czym kryterium klasyfikacji jest ilość pozostałych po zespole materiałów ${ }^{224}$. Kryterium to jest bardzo nieostre i umożliwia dużą dowolność w stosowaniu. Konarski rozszerzył nieco jego rozumienie, opisując akta władz austriackich w AGAD i stwierdzając, że „akta wyznaniowe Ministerstwa są niemal szczątkiem 45 fascykułów, powyrywanych z różnych działów administracji wyznaniowej, [co] nie daje możliwości odtworzenia ani zawartości, ani układu tej części zespołu"225. Szczątek zatem, zapewne w przeciwieństwie do zespołu fragmentarycznego, nie mówi praktycznie nic ani o samym zespole, ani o jego twórcy, nie można odtworzyć jego układu, organizacji i ustroju urzędu.

Konarski stosował zaproponowane przez siebie określenia typów zespołów w swoich pracach, wprowadzając nawet pojęcia podwójnego szczątku, szczątka szczątku zespołów czy np. szczątki trójzespołu, jakim miały być akta Sekretariatu Stanu ${ }^{226}$. O aktach tych mówi: „Charakterystyka archiwalna szczątków trójzespołu nie jest rzeczą łatwą ni prostą, ile że akta te stanowią osobliwy twór pracy kancelaryjnej czy registraturalnej”. I dalej: „Wszystkie te

221 B. Ryszewski, Z zagadnień zespotu, s. 147.

222 K. Konarski, Podstawowe zasady, s. 72.

223 Por. definicję zbioru szczątków zespołów w: Polski stownik archiwalny, red. W. Maciejewska, Warszawa 1974, s. 91.

224 K. Konarski, Podstawowe zasady, s. 73.

225 Tenże, „Akta austriackich władz centralnych w Archiwum Głównymi metoda ich porządkowania”, AGAD, AZ, sygn. 19/13, Referaty i protokoły z zebrań i konferencji naukowych 1951-1952, s. 182.

226 Tenże, Szczątkowa spuścizna aktowa po Cesarsko-Królewskiej Zjednoczonej Izbie Nadwornej (K.K. Verenigte Hofstelle), „Archeion” 1964, t. 40, s. 153. 
skomplikowane dziedzictwa i aposterioryczne reorganizacje spowodowały, że układ akt trójzespołu nie jest oparty na żadnym z obowiązujących w XIX w. systemów registraturalnych" 227 . Ale interesujące jest użycie przez niego terminu trójzespół, gdy omawia akta urzędów kontynuatorów funkcji, między którymi zaszła jednak zmiana państwowości. Widać, że rzeczywistość archiwalna wprowadzała nieraz takie zamieszanie, iż trudno było przyporządkować zespół do określonego typu. Wprowadzanie jednak takich określeń mogło być również wynikiem nie do końca przemyślenia przez Konarskiego tego zagadnienia.

Sukcesje należy zostawiać w zespole, gdyż są one konsekwencją życia, funkcjonowania urzędu. Nie należy traktować ich jako błędu. Są jednak błędy, które Konarski zaleca poprawiać. Są to błędy ludzi, kancelistów wprowadzających odchylenia od pierwotnego układu, archiwistów porządkujących błędnie, przed trafieniem zespołu do archiwum ${ }^{228}$. Musi mieć jednak pewność, że to, co uważa się za błąd, istotnie nim jest i że wykonując swoją pracę, nie popełnia się nowych błędów. W takim duchu, zgodnym z założeniami podręcznika holenderskiego, Konarski wypowiadał się również później ${ }^{229}$. Problemy te dotyczyły praktyki archiwalnej w różnych krajach, co doprowadziło do sformułowania przez Adolfa Brennekego wolnej zasady proweniencji ${ }^{230}$.

Za konsekwencję zasady proweniencji, wynikającą bezpośrednio z rekonstrukcji i porządkowania, Konarski uważał inwentaryzację zakończoną stworzeniem inwentarza. Problem inwentarza po raz pierwszy dostrzegł w recenzji podręcznika Pio Picchaiego, gdzie zauważa za Włochem, że inwentarz to stwierdzenie bytu archiwum i jego tożsamości ${ }^{231}$. A czym był inwentarz dla samego Konarskiego? „Inwentarz jest najważniejszym dokumentem archiwalnym, przewodnikiem po labiryncie akt. Brak jego utrudnia, jeśli nie uniemożliwia znalezienie szukanego dokumentu, z drugiej zaś strony odbiera

227 Tenże, Zespót akt Sekretariatu Stanu Księstwa Warszawskiego, Królestwa Polskiego oraz kancelarii J. C. Mości do Spraw Królestwa Polskiego (1807-1876), „Archeion” 1966, t. 44, s. 129.

228 Tenże, Nowożytna archiwistyka, s. 69-70.

229 Por. G. Jakubowski, dz. cyt., s. 113; K. Konarski, Podstawowe zasady archiwistyki, s. 60-62.

230 A. Brenneke, Archivkunde. Ein Beitragzur Theorieund Geschichte des europäischen Archivwesens, Lipsk 1953, s. 85-87; por. też: J. Pražak, Tak zwana wolna zasada proweniencji (z powodu wydania podręcznika teorii archiwalnej Brennekego), „Archeion” 1957, t. 27, s. 50, 53; Z. Chmielewski, Od archiwistyki, s. 59-60.

231 K. Konarski, $Z$ archiwistyki obcej, s. 132. 
możliwość przeprowadzenia w zespole kontroli jego zawartości" 232 . Zauważa zatem konieczność sporządzenia inwentarza jako stwierdzenia stanu posiadania archiwum oraz ułatwienia poszukiwań archiwalnych. Jednak w tym wyjściowym założeniu nie dostrzega bezpośredniego przełożenia zasady proweniencji na inwentarz. Definiuje jedynie inwentarz jako „spis akt zespołu archiwalnego, zawierający najważniejsze elementy rozpoznawcze poszczególnych woluminów, jak sygnatura, tytuł, data, liczba stron"233. Inwentarz systematyczny, będący wynikiem rekonstrukcji zespołu archiwalnego i jej odzwierciedleniem, jest jedynie jednym z paru typów inwentarzy, jakie zna Konarski. Zakres inwentarza też nie jest jednoznaczny. Generalnie obejmuje on zespół archiwalny, nie może odnosić się do mniejszych części, ale może zawierać kilka zespołów. Znajduje jednak w swoich rozmyślaniach miejsce na stosunek inwentarza do zasady proweniencji: ,jak zespół jest funkcją pochodną urzędu, tak inwentarz jest funkcją pochodną zespołu. Jak więc tedy zespół jest odbiciem organizacji urzędu, tak inwentarz powinien być wiernym i przejrzystym odbiciem organizacji zespołu[...] Inwentarz winien mieć układ organiczny, odpowiadać ugrupowaniom i podziałom zespołu, budowa jego jednak, jak zresztą i budowa zespołu musi mieć konieczne przejrzystość”234. Inwentarz jest odbiciem zespołu i dzieli jego losy. W przypadku przekazywania archiwum przekazane jest ono w postaci zamkniętej całości archiwalnej, a więc zaopatrzonego w inwentarze zespołu. Należy dodać, że w jego ówczesnym rozumieniu zespół tworzy się w momencie zamknięcia registratury. Gdy jest ona przekazywana innym urzędom - sukcesorom, wraz z aktami powinny zostać przekazane ich spisy - inwentarze. Konarski zatem za inwentarze uważa wszystkie spisy akt. Nie jest zatem inwentarz wynikiem wyłącznie opracowania, z zastosowaniem układu organicznego, ale każdym efektem spisania, utrwalenia poszczególnych akt zespołu. W inwentarzach-spisach akt mają także odbicie sukcesje. „Inwentarz, będący odbiciem zespołu i echem organizacji urzędu, dzielić musi losy urzędu i zespołu. Przy dziedziczeniu akt inwentarze stanowią integralną część archiwalnej sukcesji, wysuwaną zazwyczaj na pierwszy plan, jako najcenniejszą, archiwum bowiem pozbawione inwentarzy traci dla współczesnych całą, dla potomności zaś [...] znaczną część swej wartości. [...] Niekiedy dziedziczony zespół ulega do tego stopnia pochłonię-

232 Tenże, Nowożytna archiwistyka, s. 81.

233 Tamże, s. 82.

234 Tamże, s. 84 . 
ciu przez sukcesora, że granice między zespołami, a tym samem między inwentarzami zacierają się zupełnie" 235 . Użycie określenia inwentarzy w liczbie mnogiej potwierdza, że chodzi o spisy akt przekazywane wraz z aktami, częstokroć, podobnie jak akta, podlegające kontynuacjii ${ }^{236}$. Jak zatem wyraźnie widać, inwentarze te nie są wynikiem wyłącznie archiwalnego opracowania zespołu, ale spisania dokumentacji na etapie registratury danego urzędu. Spisy te jednak mają jak najbardziej organiczny układ. Jest tak np. w przypadku Kancelarii Generat-Gubernatora, do której stworzono dziewięciotomowy inwentarz opierający się na układzie akt według rocznych uwarstwowień, które w stosunku do tego zespołu są odzwierciedleniem układu organicznego ${ }^{237}$.

Takie szerokie pojęcie inwentarza Konarski podtrzymuje również później, stwierdzając, że „pojęcie inwentarz archiwalny obejmuje dość szeroki wachlarz typów, różniących się między sobą hierarchią, układem, intensywnością wyczerpania materiału aktowego, wreszcie stosunkiem do rzeczywistości”238. Uważa, że inwentarz zespołu złożonego jest pojęciem szerszym niż inwentarz zespołu prostego, jeszcze szerszym pojęciem jest inwentarz grupy zespołów. Zakres inwentarza rozszerza nawet na zbiory całego kraju, inwentarzem nazywając centralną kartotekę zespołów stworzoną przy NDAP239.

Konarski potwierdza także podwójną rolę inwentarza jako pomocy zabezpieczającej akta oraz ułatwiającej orientację w zespole, czyli jego udostępnienie zainteresowanym. Pierwsza jest równie stara jak same archiwalia, druga natomiast pojawia się znacznie później. Autor podkreśla również, że istniały pomysły, aby dla inwentarza pozostawić jedynie cel zabezpieczający, podczas gdy rolę przewodnika po aktach miałby odgrywać katalog. Propozycja ta nie przyjęła się jednak, gdyż inwentarz jest na tyle pojemny, by zaspokoić potrzeby obu funkcji.

Sama jednak inwentaryzacja jako czynność archiwalna (kończąca się stworzeniem inwentarza) jest podsumowaniem i utrwaleniem wszelkich prac archiwisty, jakie wykonał nad zespołem. Dlatego też Konarski wyraźnie różnicuje pojęcie inwentarza, który utrwala stan posiadania archiwum, nazywając go jedynie spisem akt. „Spis akt może awansować do roli inwentarza sensu stricto, jeżeli ów układ akt na półce nie jest wynikiem przypadku, ale

\footnotetext{
235 Tamże, s. 86.

236 Tamże.

237 Tamże, s. 85.

238 K. Konarski, Podstawowe zasady, s. 88.

239 Tamże.
} 
wyrazem prac rekonstrukcyjnych i porządkowych archiwisty, jeżeli, słowem, zespół został przed inwentaryzacją uporządkowany według zasad obowiązujących w archiwistyce. Inwentarz zespołu uporządkowanego według tych zasad nazwiemy inwentarzem systematycznym. Może on, ale nie musi być odbiciem akt na półkach, musi natomiast być odbiciem ustroju urzędu, z jakiego zespół pochodzi, czyli musi być opracowany według zasady przynależności zespołowej. To jest podstawowy warunek uznania inwentarza za systematyczny"240. Widać zatem większe uporządkowanie myśli na temat inwentarza wśród wielu różnych typów inwentarzy, systematyczny utrwala wykonane w zespole prace rekonstrukcyjne i porządkowe, jest tym samym przedłużeniem zasady przynależności zespołowej. Inwentarz systematyczny pozostanie w ten sposób „podstawą poszukiwań czynionych w drodze logicznego rozumowania" ${ }^{241}$. Poszukiwanie to ułatwić ma wstęp, który jest częścią składową każdego inwentarza, dającą ogólne informacje o zespole. Opracowany ma być on już po uporządkowaniu akt i powinien zawierać początkowo dzieje urzędu, dzieje zespołu oraz dzieje pomocy archiwalnych. Te części zapewniają dobrą orientację w zespole, z jego budową odzwierciedlającą organizację urzędu (dzieje urzędu), obecnym stanem będącym wynikiem przenosin, sukcesji i innych wstrząsów (dzieje zespołu), oraz ułatwiają posługiwanie się dawnymi pomocami bądź ich stosunek do obecnego inwentarza (dzieje pomocy, wcześniej dzieje inwentarza) ${ }^{242}$.

Zaproponowany przez siebie model wstępu, realizowany we własnych pracach $^{243}$, Konarski uporządkował i rozszerzył w 1952 r. Wstęp posiadający pięć części (dzieje urzędu, dzieje zespołu, charakterystyka archiwalna, zawartość zespołu i analiza metod porządkowania) „nie może mieć własnych założeń, problemów, koncepcji czy rozwiązań naukowych, jego jedynym celem winno być jasne, plastyczne zobrazowanie materiału aktowego, jego układu i zawartości oraz metod, które zostały zastosowane przy jego systematyzacji. Nie wyklucza to bynajmniej historyczno-naukowego stosunku archiwisty do owej systematyzacji, ale nie powinno to przesłaniać roli wstępu jako drogo-

\footnotetext{
240 Tamże, s. 88-89.

241 Tamże, s. 95.

242 K. Konarski, Nowożytna archiwistyka, s. 87-88; tenże, Podstawowe zasady, s. 91.

243 Por. tenże, Zespót akt Kancelarii Generat Gubernatora Warszawskiego (1831-1862) w Archiwum Akt Dawnych w Warszawie, „Archeion” 1935, t. 13, s. 83-101; tenże, Zespót akt Sekretariatu Stanu, s. 127-144.
} 
wskazu po zespole"244. Ułatwienie orientacji w zespole pozostawało naczelnym celem wstępu. Szczególną wagę przykładał Konarski do części trzeciej, do elementów archiwalnych w charakterystyce zespołu, gdyż jak sam zauważa, są one „niezbędne do należytego zrozumienia całokształtu treści akt” ${ }^{245}$.

Zasada proweniencji, jako naczelna zasada archiwistyki, nie ograniczała się jednak wyłącznie do problematyki porządkowania i inwentaryzacji. Wpływała ona także na organizację innych pomocy archiwalnych, a nawet całego zasobu archiwum. Jako że całość zasobu archiwum jest odbiciem działalności administracji, posiadają one pewien układ, nie są dziełem przypadku, zespoły dobrze zorganizowanego archiwum stanowią jednolitą, skoordynowaną całość. Układ ten powinien być odzwierciedlony w inwentarzu inwentarzy - spisie wszystkich inwentarzy zespołów znajdujących się w archiwum, który musi mieć budowę organiczną, na którą składać się będą grupy zespołów połączone chronologicznie bądź ustrojowo ${ }^{246}$. Pomoc ta oczywiście w rozumieniu Konarskiego obejmowała wszystkie pomoce ewidencyjne sporządzone do zespołu. Jak stwierdza, inwentarz inwentarzy jest „niezbędny w każdym większym archiwum, zwłaszcza posiadającym archiwalia rosyjskie typu kancelaryjnego, mnożącego, jak wiadomo, bardzo wszelkie pomoce archiwalne dzięki rocznym swym odcinkom. [...] Inwentarz inwentarzy sporządzony w swoim czasie w Archiwum Akt Dawnych dla jednego tylko zespołu akt Kancelarii Gen. Gubernatora Warszawskiego liczył z górą 2000 pozycji inwentarzy, skorowidzów i dzienników rocznych tego olbrzymiego, prawda, zespołu" 247 .

Układ, który odzwierciedlał hierarchię urzędów, będący odbiciem rzeczywistości, co można uznać za układ organiczny, miał także inwentarz generalny zespołów, czyli wykaz wszystkich zespołów znajdujących się w danym archiwum ${ }^{248}$. Odwołanie się do kryteriów ustrojowych widziałby także Konarski przy sporządzaniu ewentualnego przewodnika ${ }^{249}$. Jednak odstąpie-

244 Tenże, Wstęp do inwentarza, s. 193.

245 Tenże, Archiwum Akta Dawnych w Warszawie, [w:] Straty archiwów i bibliotek warszawskich w zakresie rękopismiennych źródet historycznych, t. 2, Warszawa 1956, s. 81.

246 Tenże, Nowożytna archiwistyka, s. 101-102.

247 Tenże, „Inwentarz inwentarzy”, AGAD, AZ, sygn. 19/14, s. 43.

248 Tenże, Podstawowe zasady, s. 99; Por. W. Kwiatkowska, Wptyw zasady proweniencji, s. 145-146.

249 K. Konarski, rec. Übersicht über die Bestände des sächsischen Landeshauptarchivs und seiner Landesarchive. Leipzig 1955, „Archeion” 1956, t. 26, s. 268. Przy omawianiu tego przewodnika Konarski stwierdza: „Przegląd wychodzi z założeń realnych, nie się- 
nie od tychże kryteriów „ustrojowo-registraturalnych” na rzecz rzeczowych w konstrukcji przewodnika uważa również za słuszne, jeśli tylko konstrukcja ta jest konsekwentna i przejrzysta, a w ten sposób znacznie ułatwia korzystanie $\mathrm{z}$ niego ${ }^{250}$.

Początkowo Konarski rozciągał układ organiczny także na skorowidze ${ }^{251}$. Jednak doświadczenia, jakie zebrał podczas sporządzania tych pomocy archiwalnych, skłaniały go do odstąpienia od organicznego układu kancelaryjnego na rzecz rzeczowego. Opinię taką wyraził na zebraniu naukowym AGAD w 1955 r., przy okazji omawiania referatu Rudawskiej nt. Akt Rady Nieustającej i ich opracowania. Referentka skłaniała się do nadania sumariuszowi układu kancelaryjnego, podczas gdy Konarski wyznał, że nie widzi zalet takiego układu ${ }^{252}$. Poważną kwestią w działalności Konarskiego było ustalenie układu sumariusza protokołów Rady Administracyjnej. W tym celu zgłosił się do środowiska naukowego o opinię. Swoje zdanie na ten temat wyraził przedwojenny współpracownik Konarskiego, Ryszard Przelaskowski, który stwierdził, że przy konstrukcji układu sumariusza „należy wyjść od układu rzeczowego, uwzględniając równocześnie kryteria ustrojowe" 253 . Ostatecznie sumariusz otrzymał układ ustrojowo-rzeczowy oparty na budowie dawnej registratury Rady Administracyjnej ${ }^{254}$. Uzasadnienie celowości tworzenia skorowidzów rzeczowych Konarski dał podczas podsumowania prac nad repertorium do zespołu akt Sekretariatu Stanu, stwierdzając, że pozwalają one zapomnieć o chaotycznej budowie inwentarza ${ }^{255}$. Widać zatem, że zauwa-

ga głębiej we wzajemne powiązania historii ustrojowej i w ewolucje strukturalne układu urzędów, choć jednak wypadałoby niekiedy dotknąć tych zagadnień”. W recenzji kolejnego przewodnika, o budowie organicznej zauważa: „są to prawie wyłącznie akta systematyzowane według zasad przynależności zespołowej, dające jasny i przejrzysty przegląd poszczególnych resortów i ich wewnętrznego rozczłonkowania”.

250 Tenże, rec. Staatsarchiv Münster und seine Bestände. T. 1, Münster 1964, „Archeion” 1967 , t. 46, s. 235-237, „Jakkolwiek można by mieć zastrzeżenia co do odchyleń od szablonu przewodnikowego, a zwłaszcza o przeroście elementu rzeczowego i osobowego, trzeba stwierdzić, że całość robi bardzo dodatnie wrażenie. Jest mimo bardzo skomplikowanego materiału aktowego przejrzysta i jasna w budowie, a to jest w literaturze przewodnikowej argument rozstrzygający".

251 Tenże, Nowożytna archiwistyka, s. 120.

252 AGAD, AZ, sygn. 19/17, Protokoty i referaty zebrań naukowych 1955, s. 3.

253 AGAD, AZ, sygn. 19/18, s. 45.

254 Sumariusz Protokotów Rady Administracyjnej Królestwa Polskiego 1815-1867, cz. 1. 1815-1830, red. K. Konarski, F. Ramotowska, Warszawa 1962, s. V.

255 K. Konarski, Zespót akt Sekretariatu Stanu, s. 133. 
żał niedomagania układu organicznego wynikającego z zasady proweniencji, który często pozostaje nieczytelny, co niwelować mają skorowidze w ogóle, a zwłaszcza rzeczowe (o układzie rzeczowym).

Jak widać z rozważań Konarskiego, zasada proweniencji była dla niego bezsprzecznie regulatorem całego życia archiwalnego. Była o tyle ważna, że regulowała pojęcie zespołu archiwalnego jako kluczowego zagadnienia w archiwistyce. Warunkiem istnienia zespołu było jego kancelaryjne pochodzenie. Nie tylko urzędowe w sensie instytucji państwowej, ale wszelkich instytucji, które mają zorganizowany system kancelaryjny. Zespół to zwarta, zamknięta, organiczna całość, powstała w wyniku działalności kancelarii.

Pojęcie zespołu archiwalnego u Konarskiego ewoluowało, podobnie zaproponowana przez niego typologia zespołów. Najwięcej miejsca poświęcał problemowi zespołu złożonego, co jednak nie przyniosło wykrystalizowania się pojęcia tego terminu, a nawet doprowadziło do pewnego powrotu i uznania, że zespół złożony tworzą zespoły wytworzone przez różne kancelarie działające w ramach jednego urzędu.

Stał jednak na stanowisku, by każdemu bytowi zespołowemu zapewnić samodzielność. Odnosiło się to przede wszystkim do szczątków zespołów. Tworzenie grup zespołów uważał jedynie za zasadne w celu zabezpieczenia małych zespołów, nie dopuszczał jednak ich merytorycznego łączenia. Rozszerzył to rozumienie, tworząc typologię zespołów całkowitych, fragmentarycznych i szczątkowych, pozostając jednak na stanowisku zachowania tożsamości każdego bytu.

Takie rozumienie przez Konarskiego zespołu i zasady proweniencji implikowało spojrzenie na dalsze czynności archiwalne jak klasyfikacja (rekonstrukcja i porządkowanie), którą poprzedzało zagadnienie sukcesji oraz inwentaryzacja. Zasada proweniencji była przez cały czas wyłącznie wyznacznikiem, nie konkretną dyrektywą, ale drogowskazem, w jakim kierunku należy podążać, by właściwie uporządkować zespół. W stosunku do inwentaryzacji i samego inwentarza jego rozmyślania uległy znacznemu sprecyzowaniu. Początkowe, bardzo szerokie rozumienie inwentarza uszczegółowił, ukazując wpływ zasady proweniencji na jego konstrukcję.

Zasada proweniencji, jako naczelna zasada archiwistyki, miała wpływ na organizację nie tylko samego zespołu, ale również całego zasobu archiwum. Zauważył jednak Konarski, że czasami zasada proweniencji nie jest gwarantem przejrzystości i jasności tej organizacji. Dlatego też widział możliwość 
odejścia od jej kategorycznego stosowania i użycia kryteriów rzeczowych przy organizacji pomocy archiwalnych.

\section{ROZMIESZCZENIE I KSZTAŁTOWANIE ZASOBU ARCHIWALNEGO W Myśli TEOretyCznej Kazimierza Konarskiego}

Opisane problemy wynikały bezpośrednio z zasady proweniencji, jednak jako że w rozumieniu Konarskiego zasada ta była główną dyrektywą życia archiwalnego, jej rozumienie wpływało też na jego poglądy na inne zagadnienia z zakresu archiwistyki. Tak było chociażby w przypadku zasady pertynencji terytorialnej czy też, jak nazywał to Konarski, związku akt z terytorium. Zagadnienie to wprowadza jako konsekwencję rozważań o sukcesjach. Stwier$\mathrm{dza}, \dot{z} e$ akta przeniesione poza terytorium, na którym powstały, są martwe, egzotyczne. Jak określa to sam Konarski, jest to „bardzo żywotny i ważki czynnik w organizacji życia archiwalnego, mianowicie związek archiwaliów z terytorium, z którego wyrosły i którego dotyczą" ${ }^{256}$. Gdzie jest miejsce w tych rozważaniach na zasadę proweniencji? Uważa, że zasada pertynencji terytorialnej może scalać archiwalia, ale w przypadku podziału administracji może przynieść skutek odwrotny w postaci podziału archiwaliów. I tutaj, o czym była już mowa, znaczenie ma zasada proweniencji, która jako nadrzędna w stosunku do zasady pertynencji terytorialnej ma rozwiązywać wszystkie trudności z niej wynikające ${ }^{257}$. Konarski zatem nie omawia zasady pertynencji terytorialnej jako odrębnej zasady regulującej życie archiwalne, ale jako czynnik wpływający na kształtowanie się zespołu archiwalnego, jako coś poniżej zasady proweniencji.

Pomimo uznania w późniejszym okresie samodzielności zasady przynależności terytorialnej, nadal omawiał ją w kontekście problemu sukcesji. Definicja zasady przynależności terytorialnej: „akta związane są z terytorium, na którym powstały lub którego dotyczą”, rozszerzona o stwierdzenie: „posiadać je i administrować niemi powinien ten, w czyim posiadaniu terytorium to pozostaje”, jest w pewnym sensie kontynuacją myśli ściśle urzędowego charakteru akt i omawiania zasady pertynencji terytorialnej w kontekście przedarchiwalnym, nie w stosunku do zarchiwizowanego zespołu archiwalnego.

256 Tenże, Nowożytna archiwistyka, s. 26.

257 Tamże, s. 28-29. 
Konarski precyzuje jednak stosunek zasady pertynencji terytorialnej do zasady proweniencji. Podkreśla, że związek akt z terytorium „jest równie silny, a czasem nawet silniejszy niż wspomniany już kilkakrotnie związek genetyczny akt ze swym macierzystym urzędem czy ze swym aktowym rodzeństwem"258. Ma to znaczenie właśnie w kontekście sukcesji, gdyż istotne jest, czy terytorium ulega podziałowi czy też nie. Zasady uznaje za równorzędne, w momencie gdy nie dochodzi do podziału terytorium. Wtedy potęgują się i sumują. Natomiast gdy dochodzi do podziału terytorium, zasada proweniencji traci swe wiodące miejsce, a nawet w pewnych okolicznościach musi ustąpić je zasadzie pertynencji terytorialnej. Jak zauważa Konarski: „jako regułę można by postawić, że o ile w obrębie jednego i tego samego kraju przeważa w decyzjach archiwalnych zasada przynależności zespołowej, to w sporach międzypaństwowych absolutnie decydujący głos ma zasada przynależności terytorialnej”259. Wpisuje się zatem w powszechny wśród polskich archiwistów pogląd o wyższości zasady pertynencji terytorialnej nad zasadą proweniencji w stosunkach międzynarodowych. Pogląd ten nie miał uzasadnienia naukowego, ale był zgodny z polską racją stanu. Tylko takie zhierarchizowanie zasad gwarantowało Polsce rewindykację i windykację archiwaliów znajdujących się w rękach państw zaborczych ${ }^{260}$.

Wraz z zasadą pertynencji terytorialnej pojawia się problem rozmieszczenia organizacji sieci archiwalnej i stworzenia jej teoretycznych podstaw. Konarski zauważa podwójne znaczenie związku akt z terytorium. Określa on związek akt z terytorium, na którym powstały, ale także zabrania mieszania akt powstałych na różnych szczeblach administracji. Wprowadza konkretne propozycje, aby akta skupić na szczeblu wojewódzkim, w celu uniknięcia zbyt dużego ich rozproszenia, jednak z wyraźnym rozgraniczeniem ich od archiwaliów władz centralnych ${ }^{261}$.

W tym duchu wypowiadał się wraz z Wincentym Łopacińskim na V Powszechnym Zjeździe Historyków Polskich w 1930 r., kiedy to padła konkretna propozycja stworzenia centralnego archiwum w Warszawie oraz rozmieszczenia archiwów terenowych (wojewódzkich). Mimo że poruszyli kwestię racjonalnego rozmieszczenia i archiwaliów oraz scalenia rozbitych zespołów,

258 K. Konarski, Podstawowe zasady archiwistyki, s. 57.

259 Tamże, s. 57-58.

260 B. Ryszewski, O badaniach i dorobku, s. 201; W. Chorążyczewski, Zasada proweniencji, s. 132-133.

261 K. Konarski, Nowożytna archiwistyka, s. 26-27. 
nie rozwinęli tego wątku ${ }^{262}$. Rozważania te powtórzył Konarski w broszurze Archiwa polskie zagrożone ${ }^{263}$. Dotychczas jednak zauważał przede wszystkim rozmieszczenie archiwaliów dla potrzeb administracji. Rozszerzył to, podobnie jak inne wątki, w Podstawowych zasadach archiwistyki, gdzie porusza też problem sieci archiwalnej, stwierdzając, że „owa sieć - to rozplanowanie i rozmieszczenie archiwum na terytorium państwa odpowiednio do struktury władz z uwzględnieniem charakteru i potrzeb środowiska, w którego zasięgu zbiory archiwalne mają być przechowywane" ${ }^{264}$. W celu racjonalnego rozmieszczenia miał zatem na uwadze już nie tylko wzgląd na potrzeby administracji, ale także na potrzeby nauki.

Problem sieci archiwalnej, zwłaszcza w okresie międzywojennym, był szeroko dyskutowany. Zdawano sobie sprawę z niedoskonałości i przejściowego charakteru sieci, która ukształtowała się na początku II Rzeczpospolitej. Dążono do jej racjonalizacji z uwzględnieniem potrzeb administracyjnych i naukowych. Propozycje Konarskiego, obok koncepcji Józefa Siemieńskiego, należały do najciekawszych i najbardziej przemyślanych ${ }^{265}$. Samemu udostępnianiu, poza ogólnymi stwierdzeniami o udostępnianiu dla potrzeb administracji i nauki, nie poświęcił Konarski w swych rozważaniach miejsca.

Istotnym natomiast okazał się dla niego problem kształtowania zasobu archiwalnego, obejmujący gromadzenie archiwaliów i selekcję. Początkowo Konarski za kształtowanie zasobu uznawał czynności związane po prostu z gromadzeniem archiwaliów, zabezpieczaniem zagrożonych materiałów i przejmowaniem ich do archiwum, ale również przejmowanie do archiwum materiałów w wyniku „archiwalnej transakcji”, dopływów z registratur, dopływów z likwidowanych urzędów, darów, depozytów prywatnych i kupna ${ }^{266}$. W jaki jednak sposób miałoby się to odbywać lub też czym powinno być poprzedzone, nie pisał. W podobnym tonie wypowiadał się później, mówiąc, jakimi drogami płyną materiały do archiwum - wskazywał na rewindykację i przejmowanie akt $\mathrm{z}$ urzędów ${ }^{267}$.

262 K. Konarski, W. Łopaciński, dz. cyt., s. 456-458.

263 K. Konarski, A. Moraczewski, Archiwa polskie zagrożone, Warszawa 1939, s. $15-16$.

264 K. Konarski, Podstawowe zasady, s. 100.

265 H. Robótka, B, Ryszewski, A. Tomczak, dz. cyt., s. 338-340.

266 K. Konarski, Nowożytna archiwistyka, s. 132-133.

267 Tenże, Podstawowe zasady archiwistyki, s. 100. 
Jednak ważnym czynnikiem, mającym wpływ na ustalenie właściwego kształtu zasobu archiwalnego było brakowanie. Pod tym stwierdzeniem ówcześnie rozumiano problem oceny dokumentacji i jej wydzielenia do zniszczenia. Konieczność brakowania materiałów była wynikiem masowości powstawania akt. Początkowo nie widział Konarski możliwości rozwiązania tego problemu jakościowo, jedynie ilościowo, przez oddzielenie „ziarna z niezliczonej ilości plew”268. Za konieczne uważał także poszerzenie powierzchni magazynowej, bo zdawał sobie sprawę, że dopływy i tak będą miały miejsce. Rozwiązanie ilościowe, a nie jakościowe pokazuje, że nie dostrzegał możliwości wprowadzenia pewnych zasad, które pozwalałyby na usuwanie większej części materiałów, nie tylko bezsprzecznej makulatury. Nie bez znaczenia w rozważaniach tych pozostaje oczywiście zasada proweniencji. Jako przykład możliwości ewentualnego brakowania większej ilości materiałów podaje listy emigrantów do rodzin w Królestwie, znajdujące się w aktach Oberpolicmajstra Warszawskiego. Uzasadnieniem dla tego typu postępowania był brak kancelaryjnego pochodzenia tych akt. Jak relacjonuje Konarski, zarząd archiwum (na czele którego stał) skłaniał się do usunięcia tych akt jako „stanowiących bezkształtną masę i nie mających żadnego bezpośredniego związku z aktami” ${ }^{269}$. Brak zatem kancelaryjnego związku materiałów z aktami zespołu sprawia, że stają się bezwartościowe.

Brakowanie uznawał on za czynność konserwatorską, jedną z najtrudniejszych i najbardziej ryzykowanych, ale w jego rozważaniach odnosiła się ona właściwie wyłącznie do brakowania materiałów znajdujących się już w archiwum, nie widział tego problemu szerzej, nie poruszał problemu selekcji na etapie przedarchiwalnym ${ }^{270}$.

Archiwistyka Kazimierza Konarskiego była nauką bardzo praktyczną i widać to także na przykładzie problemu brakowania. Wyjściem z trudnej sytuacji w jakiej znajdowały się przed wojną polskie archiwa, było m.in. ustalenie norm racjonalnego brakowania. Konarski nie zdecydował się jednak na

268 Tenże, Z zagadnień, s. 123. Zob. też W. Chorążyczewski, Zasada proweniencji, s. 122. Widać tu, że początkowo tacy archiwiści jak Konarski czy Przelaskowski godzili się jedynie na usuwanie z zespołu pustych formularzy i ewidentnych dubletów. Wynikało to z rozumienia zespołu jako zarchiwizowanej w całości registratury. Gdy mówili oni o zespole jako nie w pełni zarchiwizowanej registraturze, mieli na myśli nie efekt brakowania, lecz wypadków losowych.

269 K. Konarski, Z zagadnień, s. 123.

270 Tenże, Nowożytna archiwistyka, s. 134. 
chociażby wypunktowanie tych norm ${ }^{271}$. Zauważa za to, że w wyniku zniszczeń, jakie archiwa poniosły w II wojnie światowej, należy bardzo ostrożnie brakować materiały znajdujące się już w archiwach, gdyż mogą one posłużyć jako materiały zastępcze. Właściwie też podkreślał, że brakowanie powinno się odbyć na etapie składnicy akt, nadal jednak nie mówił, jakich akt miałoby to dotyczyć $c^{272}$. Druga wojna światowa i przemiany, jakie nastąpiły po jej zakończeniu, zmieniły poglądy Konarskiego na selekcję i moment, w którym ma się ona odbywać.

Potwierdził to w swej działalności archiwalnej podczas opracowywania akt Sekretariatu Stanu Królestwa Polskiego. Na zebraniu naukowym, na którym relacjonował prace nad zespołem, zauważył, że do brakowania nadaje się około 40\% akt, „przeważnie tych, które dotyczą spraw szczegółowych” ${ }^{273}$. Ostatecznie jednak nie usunięto tych materiałów, dochodząc do wniosku, że brakowaniu powinny podlegać tylko materiały „dojrzewające” w urzędach ${ }^{274}$. Widać, że Konarski, wartościując akta, dojrzał do myśli, że cenniejsze są akta syntetyczne, akta jednostkowych spraw natomiast - mało warte lub wręcz bezwartościowe. Jest to pogląd reprezentatywny dla rodzącej się w Polsce teorii selekcji.

Pokusił się jednak Konarski o określenie, jakie materiały uważa za wartościowe, nienadające się do brakowania. Na zebraniu naukowym pracowników AGAD wyraził pogląd, że nie zgadza się z twierdzeniem, jakoby akta najniższej instancji były bezwartościowe. Uważa, że co prawda tracą one na rozległości, ale pokazują sprawy jednostkowe i mają dużą wartość badaw$\mathrm{czą}^{275}$. Jest to twierdzenie dość dziwne, zwłaszcza w kontekście problemu brakowania materiałów Sekretariatu Stanu, jest to jednak bodajże jedyny wkład Konarskiego do teorii selekcji.

Jego poglądy na selekcję ewidentnie dojrzewały. Widać to w kontekście recenzji podręcznika Konstantina Grigorjewicza Mitiajewa. Mimo że Konarski uważa brakowanie za mniej ważny problem archiwalny, o samym brakowaniu pisze: „Zakrawa to na paradoks, ale racjonalne brakowanie akt jest jednocześnie ich konserwacją i uwypukleniem. Z jednej strony w krańcowo chronicznie przeładowanych aktami archiwach daje brakowanie nieco miej-

\footnotetext{
271 K. Konarski, W. Łopaciński, dz. cyt., s. 15.

272 K. Konarski, Podstawowe zasady, s. 102.

AGAD, AZ, sygn. 19/14, s. 9.

274 K. Konarski, Zespót akt Sekretariatu Stanu, s. 133.

275 AGAD, AZ, sygn. 19/18, s. 206.
} 
sca, a więc możliwość racjonalniejszego zagospodarowania i lepszego technicznie przechowywania zachowanej ich części, a po wtóre usunięcie balastu akt zbędnych, otwiera w tym gąszczu perspektywy, ujawnia, uwypukla i dobywa spod szarzyzny aktowej rzeczy, które na to wydobycie zasługują"276. Zgadza się zatem oprócz wspominanego przez niego usuwania „balastu”, na brakowanie szerszych partii materiałów, dla ułatwienia badań. Widać znaczny przełom w postrzeganiu przez Konarskiego brakowania. Istotę brakowania wyraża także przy omawianiu samego terminu brakowanie, w odniesieniu do rosyjskiego słowa ekspertyza. Zastanawia się, „czemu wybrano ten żywcem z terminologii podręcznika zaczerpnięty wyraz ekspertiza, zamiast zastąpić go właściwym polskim słowem brakowanie, które jest o tyle wierniejszym terminem od ekspertyzy, że ta ostatnia w polskim znaczeniu zawiera tylko moment oceny wartości akt, podczas gdy termin brakowanie, prócz momentu oceny, uwzględnia bardzo ważny w danym wypadku moment wydzielenia, usuwania z akt bezwartościowego materiału"277. Jest to literalny wyraz jego wcześniejszych poglądów, zgodnych z ówczesnym postrzeganiem brakowania.

Kazimierz Konarski dostrzegał szeroki aspekt zagadnień archiwalnych, jednak jego ścisłe skupienie się na zasadzie proweniencji nie pozwoliło mu na szersze rozwinięcie tych wątków. W początkowym okresie widać wyraźnie połączenie wszystkich pod jednym szyldem zasady proweniencji. Rozumienie zasady pertynencji terytorialnej czy też brakowania odbywało się wyłącznie w kontekście tej zasady. Po wojnie Konarski zauważył samodzielność tych problemów, nie zdobył się jednak na ich rozwinięcie, skupiając się już przede wszystkim na praktykowaniu archiwistyki.

\section{ZAKOŃCZENIE}

Kazimierz Konarski był, tak jak twierdzi Bohdan Ryszewski, przede wszystkim metodykiem ${ }^{278}$. Jednak jego duże doświadczenie archiwalne pozwalało mu na wyciąganie teoretycznych wniosków i uogólnień. Praca archiwalna Konarskiego skupiała się przede wszystkim na opracowaniu zasobu archiwalnego i jego organizacji, co przyniosło wymierne korzyści metodyczne w po-

\footnotetext{
${ }^{276}$ K. Konarski, rec. Mitjaev K. G., Teoria i praktyka, s. 255.

277 Tamże, s. 256.

278 B. Ryszewski, O badaniach i dorobku, s. 176.
} 
staci tworzenia systematyki pomocy archiwalnych oraz (głównie w okresie powojennym) wytycznych metodycznych do opracowania różnych typów dokumentacji. Doświadczenie jego w małym stopniu obejmowało problemy brakowania czy udostępniania archiwaliów. Za to sprawowanie funkcji kierowniczych $\mathrm{w}$ archiwach pozwoliło mu na poznanie organizacji archiwów i mechanizmów funkcjonowania służby archiwalnej. Warto podkreślić, że okres powojenny działalności Kazimierza Konarskiego nie przyniósł właściwie żadnych istotnych ustaleń w jego myśli. Działalność archiwalna nie obejmowała nowych, nieznanych Konarskiemu czynności, nie wniosła zatem do myśli Konarskiego nowych wątków.

Utrzymywanie się w stylistyce przedwojennej bardzo dobrze widać w jego pojmowaniu archiwistyki. Najlepszym tego przykładem jest jego recenzja podręcznika Mitiajewa. Radziecki uczony dostrzegał już wagę, jaką ma i będzie miała w przyszłości problematyka kształtowania zasobu. Konarski natomiast skrytykował szczegółowe potraktowanie przez niego tej problematyki kosztem opracowania zasobu, które dla Konarskiego pozostawało zagadnieniem centralnym w działalności archiwów.

To właśnie działalność archiwów wyznaczała w myśli Konarskiego zakres archiwistyki. Najważniejszą funkcję pełniła oczywiście problematyka porządkowania i inwentaryzacji zasobu, a wynikało to z centralnej roli zespołu archiwalnego, który był dla Konarskiego przedmiotem badań archiwistyki. Zakres archiwistyki widział Konarski bardzo szeroko. Włączał do niego wszystkie czynności, jakie wykonują archiwiści (z jakimi on miał styczność, pracując w archiwum), w tym nawet problematykę tworzenia i prowadzenia biblioteki archiwalnej czy atmosferę w archiwum. Jednakże tak szerokie rozumienie archiwistyki, dostrzeganie wielu drobnych zagadnień, spowodowało brak przejrzystości i porządku w zaproponowanym przez niego zakresie, co najlepiej widać na przykładzie planowanego przez niego podręcznika archiwistyki.

Sam przedmiot archiwistyki zasadniczo się nie zmieniał, zmianie natomiast ulegał punkt ciężkości, nacisk, jaki Konarski kładł na poszczególne zagadnienia. Początkowo kluczową kwestię odgrywała zasada proweniencji, następnie skupił się bardziej na pojęciu samego zespołu, by ostatecznie uznać, że kamieniem węgielnym archiwistyki jest wykrystalizowanie się pojęcia aktu. Podejście takie jest ewidentnie uleganiem pewnym modom. Widać początkowe zachłyśnięcie się zasadą proweniencji, a następnie przejście, bez wątpienia pod wpływem Meissnera, na pozycje aktoznawcze. 
Konsekwentnie Konarski utrzymywał pogląd o konieczności stworzenia polskiej odmiany archiwistyki. Uważał, że archiwistyka nie jest nauką uniwersalną i musi posiadać swój lokalny charakter i wydaje się, że tego dokonał. Walnie przyczynił się do stworzenia polskiej, specyficznej archiwistyki, skupiającej się na zagadnieniach aktu i kancelarii, żądającej szczegółowego opisu archiwaliów, różniącej się przynajmniej w tym zakresie od archiwistyki światowej. Potwierdzić to mogłyby szczegółowe badania recepcji dorobku Kazimierza Konarskiego i porównanie ich z ogólnym teoretycznym dorobkiem archiwistyki światowej.

Znając doświadczenie zawodowe Kazimierza Konarskiego i sposób jego formułowania wniosków teoretycznych, jako uogólnienia praktycznej działalności, jest zrozumiałe, że centralne miejsce w jego rozważaniach zajęła zasada proweniencji i problematyka zespołu archiwalnego. Dokładne rozważania co do istoty zasady proweniencji pozwoliły Konarskiemu na stworzenie typologii zespołów archiwalnych, w tym przede wszystkim podniesienie problemu zespołu złożonego. Zasadę proweniencji, jako naczelną zasadę archiwistyki, rozciągał także na organizację zasobu archiwum (który również posiada swoją organiczną budowę) i pomocy archiwalnych.

Podobnie nie może dziwić tak marginalne zajęcie się problemami rozmieszczenia i brakowania zasobu, gdyż Konarski w tym zakresie posiadał bardzo małe doświadczenie. Nie bez znaczenia w tych kwestiach pozostawała zasada proweniencji. Kancelaryjne pochodzenie akt było warunkiem ich wartości. Wszystko, co było niekancelaryjne, wartość tę traciło. Mimo dostrzeżenia w okresie powojennym innego znaczenia i wartości brakowania, Konarski wątku tego już w swych rozważaniach nie rozwinął.

Postać Kazimierza Konarskiego trwale wpisała się w historię polskiej archiwistyki. Jednak czy może to dziwić, skoro jest on twórcą, pierwszym i być może głównym propagatorem polskiej odmiany archiwistyki?

\section{Bibliografia:}

Archiwum Akt Dawnych w Warszawie w latach 1918-1926, „Archeion” 1927, t. 2.

Bańkowski Piotr, Kazimierz Bogdan Konarski (27 maja 1886-3 listopada 1972), „Archeion” 1973, t. 59.

Brenneke Adolf, Archivkunde. Ein Beitrag zur Theorie und Geschichte des europäischen Archivwesens, Lipsk 1953. 
Chorążyczewski Waldemar, Myśl archiwalna Kazimierza Artamowskiego, „Rocznik Historyczno-Archiwalny" 2012, t. 22.

Chorążyczewski Waldemar, Myśl archiwalna Ryszarda Przelaskowskiego (1903-1971), [w:] Wioletta Guzek, Waldemar Chorążyczewski, Joanna Popłońska, Ryszard Przelaskowski. Dyrektor, bibliotekarz, archiwista, , Warszawa 2010.

Chorążyczewski Waldemar, Zasada proweniencji w polskiej myśli archiwalnej do roku 1939, [w:] Torunskie konfrontacje archiwalne, t. 2: Teoria archiwalna wczoraj-dzis-jutro, red. W. Chorążyczewski, A. Rosa, Toruń 2011.

Chmielewski Zdzisław, Od archiwistyki „bez zasad” do archiwistyki „bez granic” - czyli archiwistyka europejska od Casanovy do Papritza, „Archiwista Polski” 2007, nr 2.

Chmielewski Zdzisław, Polska myśl archiwalna w XIX i XX wieku, Warszawa-Szczecin 1994.

Degen Robert, Myśl archiwalna Ryszarda Mienickiego, [w:] Ryszard Mienicki (1886-1956). Archiwista i historyk, red. W. Chorążyczewski i R. Degen, Toruń 2009.

Jankowska Jadwiga, Dziatalność Sekcji Archiwalnej Warszawskiego Kota Związku Bibliotekarzy i Archiwistów Polskich w Warszawie w 1947 r., „Archeion” 1948, t. 17.

Konarski Kazimierz, Archiwalia tódzkie w Archiwum Akt Dawnych w Warszawie, „Rocznik Łódzki” 1928, t. 1.

Konarski Kazimierz, Dalekie a bliskie. Wspomnienia szczęśliwego cztowieka, Wrocław-Warszawa-Kraków 1965.

Konarski Kazimierz, Nowożytna archiwistyka polska i jej zadania, Warszawa 1929.

Konarski Kazimierz, $Z$ archiwistyki obcej, rec. podręcznika Pio Pecchiai, Manuale prawico per gliarchivisti, Milano 1928, „Archeion” 1928, t. 4.

Konarski Kazimierz, $Z$ zagadnień nowożytnej archiwistyki polskiej, „Archeion” 1927, t. 1.

Konarski Kazimierz, Szczątkowa spuścizna aktowa po Cesarsko-Królewskiej Zjednoczonej Izbie Nadwornej (K.K. VerenigteHofstelle), „Archeion” 1964, t. 40.

Konarski Kazimierz, Zespót akt Kancelarii Generat Gubernatora Warszawskiego (1831-1862) w Archiwum Akt Dawnych w Warszawie, „Archeion” 1935, t. 8.

Konarski Kazimierz, Zespót akt Sekretariatu Stanu Księstwa Warszawskiego, Królestwa Polskiego oraz kancelarii J. C. Mości do Spraw Królestwa Polskiego (1807-1876), „Archeion” 1966, t. 44.

Konarski Kazimierz, [rec.:] H. O. Meisner, Urkunde Und Aktenlehre der Neuzeit, Leipzig 1950, „Studia Źródłoznawcze” 1958, t. 2.

Konarski Kazmierz, [rec.:] Staatsarchiv Münster und seine Bestände. T. 1, Münster 1964, „Archeion” 1967, t. 46.

Konarski Kazimierz, [rec.:] Übersicht über die Bestände des sächsischen Landeshauptarchivs und seiner Landesarchive. Leipzig 1955, „Archeion” 1956, t. 26.

Konarski Kazimierz, [rec.:] Z archiwistyki kościelnej, „Ateneum Kaptańskie”, t. 36, 1935, s. 523-533, „Archeion” 1937-1938, t. 15. 
Konarski Kazimierz, Łopaciński Wincenty, Reorganizacja archiwów państwowych, [w:] Pamiętnik V Powszechnego Zjazdu Historyków Polskich w Warszawie, red. K. Tyszkowski, Lwów 1930.

Konarski Kazimierz, Moraczewski Adam, Archiwa polskie zagrożone, Warszawa 1939.

Kwiatkowska Wiesława, Tradycyjny model opracowania zasobu archiwalnego i jego znaczenie w dobie wspótczesnej, „Archiwa - Kancelarie - Zbiory” 2010, nr 1 (3).

Kwiatkowska Wiesława, Wptyw zasady proweniencji na metodykę opracowania zasobu archiwalnego $w$ Polsce, [w:] Torunskie konfrontacje archiwalne, t. 2: Teoria archiwalna wczoraj-dziś-jutro, red. W. Chorążyczewski, A. Rosa, Toruń 2011.

Leśniewska Klaudia, „Program prac wewnętrznych $w$ archiwach nowożytnych” Ryszarda Przelaskowskiego jako rozwinięcie myśli Kazimierza Konarskiego czy inne spojrzenie na archiwistykę?, „Archiwista Polski” 2012, nr 1.

Maciejewska Wanda, Konarski Kazimierz Bogdan (1886-1972), [w:] Stownik biograficzny archiwistów polskich, red. M. Bielińska, I. Janosz-Biskupowa, t. 1: 1918-1984, Warszawa-Łódź 1988.

Mamczak-Gadkowska Irena, Archiwa państwowe w II Rzeczypospolitej, Poznań 2006.

Meisner Heinrich Otto, Aktenkunde. Ein Handbuch für Archivbenutzer mit besonderer Berücksichtigung Brandenburg-Preußens, Berlin 1935.

Meisner Heinrich Otto, Urkunde und Aktenlehre der Neuzeit, Leipzig 1950.

Polski stownik archiwalny, red. W. Maciejewska, Warszawa 1974.

Pražak Jiři, Tak zwana wolna zasada proweniencji (z powodu wydania podręcznika teorii archiwalnej Brennekego), „Archeion” 1957, t. 27.

Ryszewski Bohdan, O badaniach i dorobku archiwistyki polskiej z lat 1918-1939, „Acta Universitatis Nicolai Copernici, Historia” 1984, nr 19.

Ryszewski Bohdan, O niektórych podstawowych pojęciach archiwalnych (kancelaria, registratura, zespót archiwalny, archiwum), „Zeszyty Naukowe UMK, Historia” 1969, nr 5.

Robótka Halina, Ryszewski Bohdan, Tomczak Andrzej, Archiwistyka, Warszawa 1989.

Sprawozdanie z dziatalności Archiwów Państwowych, rok 1927, red. W. Łopaciński, „Archeion” 1930, t. 5, Dział Urzędowy.

Sprawozdanie z dziatalności Archiwów Państwowych, rok 1928, 1929, red. W. Łopaciński, „Archeion” 1930, t. 6-7, Dział Urzędowy.

Sprawozdanie z dziatalności Archiwów Państwowych, rok 1930, red. W Łopaciński, „Archeion" 1931, t. 9, Dział Urzędowy.

Sprawozdanie z dziatalności Archiwów Państwowych, rok 1931, oprac. W Łopaciński, „Archeion" 1932, t. 10, Dział Urzędowy.

Sprawozdanie z dziatalności Archiwów Państwowych, rok 1932, oprac. W Łopaciński, „Archeion" 1933, t. 11.

Sprawozdanie z dziatalności Archiwów Państwowych, lata 1933 i 1934, oprac. A. Rybarski, „Archeion” 1935, t. 13. 
Sprawozdanie z dziatalności Archiwów Państwowych, rok 1935, oprac. A. Rybarski, „Archeion" 1936, t. 14.

Sprawozdanie z dziatalności Archiwów Państwowych, rok 1936, oprac. A. Rybarski, „Archeion" $1937-1938$, t. 15.

Sprawozdanie z dziatalności Archiwów Państwowych, rok 1937, oprac. A. Rybarski, „Archeion" 1938-1939, t. 16.

Stępniak Władysław, Misja Adama Stebelskiego. Rewindykacja archiwaliów polskich z Niemiec w latach 1945-1949, Warszawa-Łódź 1989.

Sumariusz Protokotów Rady Administracyjnej Królestwa Polskiego 1815-1867, cz. 1: 1815-1830, red. K. Konarski, F. Ramotowska, Warszawa 1962.

Tomczak Andrzej, Archiwistyka polska (1918-1969). Z dziejów ksztaltowania się dyscypliny naukowej i jej nazwy, „Rocznik Biblioteki Narodowej” 1972, r. 7.

\section{Summary}

Theoretical archival thought of Kazimierz Konarski (1886-1972)

Kazimierz Konarski was most of all a methodologist. But his wide experience in archives enabled him to draw theoretical conclusions and generalizations. The archival work of Konarski was focused mostly on arrangement and description of archival holdings and on organizing it, which gave notable methodological effects in the form of systematics of archival aids and methodological guidelines for arrangement and description of various types of documents. For Konarski arrangement and description of archival holdings was always a central problem in archives' activity. To a small degree his experience involved problems of disposal and providing access to archival materials. But performing leading functions in archives enabled him to get to know the organization of archives and mechanisms of functioning of the archival service. In the thought of Konarski, the scope of archival science was outlined by activities of archives. Problems of arrangement and inventorying of archival holdings occupied a crucial role. It was a consequence of the central position of a fonds, which was, for Konarski, the subject of archival science. Konarski understood the scope of archival science very widely. In this scope he included all the activities performed by archivists, even issues of building up and running an archival library or the atmosphere of an archive. The subject of archival science itself did not change. What did change was emphasis placed by Konarski on particular problems. First, the crucial issue for him was the principle of provenance, then he focused on the understanding of an archival fonds. Finally Konarski recognized that the cornerstone to archival studies is the process of crystallizing the term "record" ("akt"). This approach is clearly an effect of being influenced by some fashion. What can be seen is, at first, relishing the principle of provenance, and then turning towards diplomatics, certainly under the influence of 
Meissner. Konarski consequently held his view on the necessity of creating the Polish version of archivistics. He thought that archival science is not a universal discipline and that it has to have a local character, what he probably achieved. He made a key contribution to creating the specific, Polish archival science, focused on issues of records and office, demanding a detailed archival description, at least in that different from the world archivistics. Kazimierz Konarski has become an inherent part of history of Polish archival science. But could it be a surprise, if he is the creator, the first and maybe the main promoter of the Polish version of archivistics? 
